\title{
Bankers on the Board and CEO Turnover
}



Y. Han (Andy) Kim² $\quad$ Jeung-Yoon (Jen) Chang ${ }^{3}$

\begin{abstract}
Governance literature finds that the independent directors from the lending banks (CBDs) bring both financial expertise and conflict of interest between shareholders and debtholder. We examine how the presence of CBDs affects the implicit incentive of CEO turnover. Using BoardEx and DealScan data, we hypothesize and find that CBDs make the CEO turnover more sensitive to both performance and risk. Post CEO turnover analysis reveals that firm performance improves and risk decreases in the presence of CBDs.
\end{abstract}

Keyword: CEO turnover, banker directors, board of directors, commercial bankers, corporate governance, implicit incentive

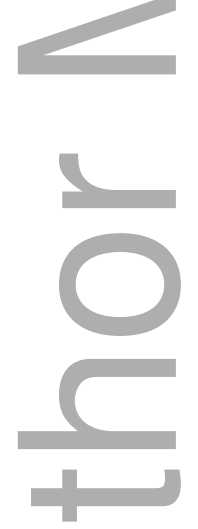

\footnotetext{
${ }^{1}$ Correspondent author: Assistant professor of Finance, School of Management, University of Michigan-Flint, $303 \mathrm{E}$. Kearsley Street, 2138 Riverfront Center, Flint, MI 48502, USA Contact info: +1-810-424-5313; kangmin@umich.edu Part of this paper comes from the first chapter of Min Jung Kang's doctoral dissertation at Michigan State University.

2 Associate Professor of Finance at SKKU (SungKyunKwan University), Room \#524, Business school bldg., SungKyunKwan University, Jongno-gu, Seoul, Korea, 110-746. Email: ayhkim@skku.edu. This is the author manuscript accepted for publication and has undergone full peer review but has not been through the copyediting, typesetting, pagination and proofreading process, which may lead to differences between this version and the Version of Record. Please cite this article as doi: $\underline{10.1111 / A J F S .12288}$
} 
${ }^{3}$ Doctoral student at SungKyunKwan University, Room \#327, Business school bldg., SungKyunKwan University, Jongno-gu, Seoul, Korea, 110-746. Email: jenjychang@skku.edu

Special thanks are due to G. Geoffrey Booth and Jun-Koo Kang, who gave the authors great support and encouragement. We also thank the seminar participants at the SKKU-Peking University Forum; the Korean Securities Association seminar; California State University, San Bernardino; Hofstra University; Korea University; Menlo College; Michigan State University; Seoul National University; SKKU; and the University of Michigan-Flint. We thank Joon Chae, Sungwook Cho, Henrik Cronqvist, Mara Faccio, C. Edward Fee, Gustavo Grullon, Charles J. Hadlock, Jarrad Harford, Gerard Hoberg, Cliff Holderness, Mark Huson, Dirk Jenter, Li Jin, Dong-Soon Kim, Joong Hyuk Kim, Jungwook Kim, Noolee Kim, Woo Chan Kim, Woojin Kim, Ron Masulis, Michael Mazzeo, William L. Megginson, Hyun Seung Na, Kwang Woo Park, Sheridan Titman, Fei Xie and JunYang for insightful comments and suggestions. We thank Dirk Jenter for graciously sharing the CEO turnover data for 1993-2001 period. The authors also appreciate Moody's KMV for providing the expected default frequency data for our sample firms. We are grateful to the excellent research assistance of Youngjae Jay Choi, Brian He, Denise Heng, Joyce Tan and Alvin Wei. All errors are our own.

\section{Introduction}

Board of directors play an important role of monitoring and advising the top managers (Adams, Hermalin, and Weisbach, 2010). Among all, independent directors from commercial banks (CBDs), receive much more attention from the economists (Black and Scholes, 1973; Booth and Deli, 1999; Güner, Malmendier and Tate, 2008; Hilscher and Şişli -Ciamarra, 2013; Kang and Kim, 2017; Kang, Kim, and Liao, 2019; Kroszner and Strahan, 2001; Mitchell and Walker, 2010; Sişli-Ciamarra, 2012), because they bring both financial expertise and conflict of interest between shareholders and debtholders.

Through career training in commercial banking, CBDs become experts in risk management (John, Litov, and Yeung, 2008; Weinstein and Yafeh, 1998) and in processing financial accounting information (Fama and Jensen, 1983; Weisbach, 1988). While CBDs have a fiduciary duty to protect the shareholders' interests that are by definition more risk tolerant than debt holders, they (especially the ones from lending banks) equally have important fiduciary duty to their employing banks, to minimize firm risk (Jensen and Meckling, 1976; Hilscher and Şişli-Ciamarra, 2013; Erkens, Subramanyam, and Zhang, 2014; Kang and Kim, 2017). Kang and Kim (2017) find that CBDs influence CEO's compensation structure to be less sensitive to firm risk. While compensation is an explicit incentive, the threat of dismissal is an implicit incentive to extract 
best effort of the agent (Gibbons and Murphy, 1990; Kwon, 2005; Hallman, Hartzell, and Parsons, 2011). No paper has investigated the impact of CBDs on CEO turnover. Hence, we fill this gap in this paper.

If CBDs bring more financial expertise to the board, CEO dismissal would be more sensitive to firm performance ("financial expertise hypothesis"). On the other hand, if CBDs bring conflicts of interest to minimize firm risk, CEO turnover would be more sensitive to firm risk ("conflict of interest hypothesis"). These two hypotheses are not necessarily mutually exclusive, and testing them would bring a complete picture about the impact of CBDs on CEO incentives as a whole.

Using the intersection of BoardEx, DealScan, and CRSP/Compustat over 1999-2008, we find that CEO turnover is more sensitive to performance when CBDs are present. The effect is stronger for affiliated banker directors (ABDs). While average investor response to the forced CEO turnover news is negative, such announcement return is significantly positive if CBDs are present, and even more so if prior performance was poor. Additionally, we track down the cases of forced CEO turnovers and analyze the subsequent performance under new CEOs. We find significant improvements in operating performance for firms with CBDs, and this is especially true when prior performance was poor. These results coherently support the "financial expertise hypothesis."

We also find supporting evidence for "conflict of interest hypothesis." The likelihood of CEO dismissal increases as firm risk increases, especially when ABDs are present. Our postturnover risk analysis shows that for firms with CBDs, idiosyncratic risk after CEO turnoveryear further decreases when prior risk is high.

Overall, we find that CBDs, especially ABDs, are double edged sword in providing CEO's implicit incentive. Their financial expertise makes CEO turnover more sensitive to firm performance, but their conflict of interest makes the turnover sensitive to risk, which may be against shareholder's interests.

The remainder of this paper is organized as follows: Section 2 provides literature review and main hypotheses, and Section 3 describes our data and empirical methods. Section 4 presents main empirical findings and Section 5 concludes our study. 


\section{Literature and Hypotheses development}

Previous research suggests that effective boards show higher sensitivity to performance when firing a CEO (see Weisbach, 1988; Agrawal and Nasser, 2019; Dahya, McConnell, and Travlos, 2002; Dimopoulos and Wagner, 2016; Adams and Ferreira, 2009). Wang, Xie, and Zhu (2015) suggest that directors' industry expertise improves the board's oversight role, which increases CEO turnover-performance sensitivity. Since commercial bankers amass greater financial expertise and better debt market expertise (Diamond, 1984; Fama, 1980; Byrd and Mizruchi, 2005; Dittman et al, 2010; Booth and Deli, 1999), we predict that these CBDs are better positioned to effectively work as monitors leading CEO turnovers to be more sensitive to firm performance (Kang and Shivdasani, 1995). In addition, ABDs show intensive monitoring due to their affiliation with their own firm (Kang and Kim, 2017). Therefore, we predict the following:

H1) For firms with CBDs, forced turnover is more sensitive to firm performance and this effect would be more pronounced as there are more ABDs.

Bankers are different from entrepreneurs in perceiving and managing risks (Sarasvathy, Simon, and Lave, 1998). They focus more on controlling risks and try to avoid situations where they may face higher levels of risk (Mitchell, 2015; Kang and Kim, 2017; Kang, Kim, and Liao, 2019). This is because an increase in a bank's tail risk imposes more hardship and costs to its operation (Stulz, 2015; Srivastav, Keasey, and Vallascas, 2017). Thus, banker's sensitivity to firm risk even as a board member may be a natural response. Hence, ABDs should be

particularly more sensitive to risk measures for CEO turnover decisions, which leads to our second prediction:

H2) ABDs will be more sensitive to firms' risks on CEO turnover.

With respect to CEO turnover announcement, stock prices rise when forced dismissals are congruent with shareholders' interests (Huson, Parrino, and Starks, 2001). And this effect is stronger when $\mathrm{CEO}$ is dismissed in firms with poor prior firm performance or with good corporate governance (Huson et al. 2001; Bonnier and Bruner, 1989; Furtado and Rozeff, 1987; Weisbach 1998). We predict that such forced turnover announcement effect will be more positive for firms with CBDs because CBDs provide industry-specific financial expertise, are trained to monitor actively, and can make better decisions with private information (Diamond, 1984; Fama, 1985; Byrd and Mizruchi, 2005; Dittman et al, 2010; Booth and Deli, 1999). Hence, 
if the market perceives CBDs as better monitors and fire CEOs with poor firm performance, the stock market would react more favorably to the news. We therefore formalize H3 and H4 as follows:

H3) When CEO turnover is announced, firms with more CBDs will result in a more positive stock market reaction compared to firms with less or without CBDs.

H4) For firms with CBDs, the market perceives forced turnover news more positively when prior performance is poor.

Kang and Shivdasani (1995) and Dimopoulos and Wagner (2016) both find that firm performance improved after CEO was dismissed of lackluster firm performance. Likewise, if CBDs dismissed CEOs to correct prior poor firm performance (i.e. if our $H 4$ holds), firm postperformance should improve after the CEO turnover. Therefore, our H5 is stated as follows:

H5) After the CEO turnover, firm performance improves more for firms with CBDs than for those without CBDs. This enhancement in firm performance will be stronger for firms with $C B D$ s when firm's prior performance was poor.

\section{Data and Empirical Methods}

\section{III.1 Data}

Board of directors data is obtained from BoardEx. ${ }^{1}$ After running extensive text matching algorithms, we obtain an exhaustive link of 27,034 unique firms that can be matched with Compustat. ${ }^{2}$ We identify CBDs by following Guner et al. (2008) in defining an ABD who works for a bank that currently has or had a loan exposure to the monitored company in at least one point in time during its history. Firm characteristic variables are from CRSP and Compustat while CEO characteristics are obtained from Execucomp. ${ }^{3}$ KMV Expected default frequency measures the default probability during the forthcoming year which we obtained from Moody's KMV.

CEO turnover data on and before 2001 has been provided by Dirk Jenter. ${ }^{4}$ For CEO turnover data from 2002 to 2008, we hand collected them following Jenter and Kanaan (2015). In We follow Parrino (1997) to identify whether a CEO turnover was forced or voluntary, using Factiva (see Bushman et al., 2010; Jenter and Kanaan, 2015; Kaplan and Minton, 2012). ${ }^{5}$ Voluntary turnovers produce mixed results or sometimes insignificant results due to various 
unobservable reasons behind the turnovers (Huson et al., 2001). As regards, our paper, along with the extant literature, will focus only on the forced CEO turnovers.

\section{III.2 Empirical method}

In all multivariate analyses, all continuous variables are winsorized at $1 \%$ and $99 \%$ levels to mitigate possible distortion caused by outliers. To proxy firm performance, we use industry median adjusted ROA. ${ }^{6}$ Industry is classified using Fama-French 49 industry classifications using the current SIC code. ${ }^{7}$ We use several risk measures for firm risk: ROA risk, idiosyncratic risk, stock return risk, and KMV Expected default risk. ROA risk is the standard deviation of a firm's prior five years of industry median adjusted quarterly ROA. Idiosyncratic risk is constructed by retrieving the root mean squared error after regressing daily stock returns on the CRSP value-weighted index (Bushman et al., 2010). Stock return risk is the standard deviation of a firm's annualized daily stock return. KMV Expected default risk (KMV EDF) is provided by Moody's, which measures firm's default probability in the forthcoming year.

Prior research shows that larger boards and/or boards where CEO is chairman of the board (Fama and Jensen, 1983) are considered weak. Weak boards have lower CEO turnoverperformance sensitivity, indicating board's less monitoring of top management (see Goyal and Park, 2001). Dikolli, Mayew, and Nanda (2014) further explain that CEO turnover sensitivity declines with tenure. Accordingly, we control for such factors in our forced CEO turnover regressions. We follow Adams and Ferreira (2009) controlling for the fraction of independent directors and its interaction terms in all regression specifications.

\section{Empirical results}

\section{IV.1 Summary statistics}

Table 1 presents the distribution across industries. Approximately $9.36 \%$ of all firm-years in our sample have at least one CBDs.

[Insert Table 1 here]

Table 2 presents the summary statistics for firm-years of full sample and between two groups whether they have a CBD or not. It appears that CBDs sit on boards of larger firms, firms with less cash flow, and less risky firms, consistent with the literature that bankers tend to sit on boards of less risky firms but are less in need of bankers. Also, Table 2 shows that CBDs are on 
boards with weak governance; i.e. boards whose chairman is a CEO, and firms with an insider CEO, with less CEO ownership, with larger board size, and with less independent directors.

[Insert Table 2 here]

\section{IV.2 Forced turnover regressions}

Table 3 uses logit model where the dependent variable is an indicator variable equal to one when there is a forced turnover. All specifications in Table 3 include industry and year dummies to control for time invariant unobservable heterogeneity. Table 3, columns (1) and (2) show that simply having outsider directors or CBDs do not have a significant relationship on CEO turnover decisions. On the other hand, Table 3 columns (3) and (4) show that as there are more ABDs, CEO will be more likely be fired, especially when prior ROA performance is poor. The coefficient estimates of NABDs, and its interaction terms with ROA performance show statistical insignificance as well as smaller economic magnitude. ${ }^{8}$ Overall, Table 3 results are consistent with Mitchell (2015) and Şişli-Ciamarra (2012) that ABDs are the ones who have the most incentive to monitor.

[Insert Table 3 here]

Table 4 results indicate that ABDs are also sensitive to firm risk on CEO turnover as the interaction coefficients with risk measures show a statistically significant positive sign in all Panels. It is interesting to see that CEO turnover is sensitive to risk measure only for the firms with more ABDs. This effect is economically significant as well, as can be seen by the marginal effects of column (4) (shown in column (5)) in Table 4 Panel A. On the other hand, none of the NABDs are associated with risk measure on CEO dismissals, except when risk is proxied by ROA risk (see Panel C). However, we find that coefficient estimate on the interaction between \%ABD and ROA risk in column (4) is significantly larger than that between \%NABD and ROA risk. This implies that ABDs are more sensitive to firm risk than any other types of CBDs, resulting in more CEO dismissals. This implies that CEOs' dismissals are risk-sensitive with ABDs, whereas NABDs are not/less responsive to firm's risk. This is consistent with the view that creditors are risk-averse (Jensen and Meckling, 1976; Sarasvathy et al., 1998). ${ }^{9}$

[Insert Table 4 here]

Overall, results in Table 3 and 4 suggest that ABDs are performance sensitive but also sensitive to firms' risk on CEO's dismissal unlike other independent directors. These results support our $\mathrm{H} 1$ and $\mathrm{H} 2$. 


\section{IV.3 Announcement returns on forced CEO turnover news}

In this section we see whether CBD's presence yields any positive effect on shareholder's wealth when CEO forced turnover is announced. We use data that have both CEO forced turnover data and BoardEx data. As regards, we start with a total of 351 forced turnovers. Among them, 17 observations are deleted due to confounding events ${ }^{10}$ and any observations with missing financial data are eliminated. As a result, we use 317 forced turnovers to examine the CEO turnover announcement effect.

Table 5, Panel A reports abnormal returns (ARs) and cumulative abnormal returns (CARs) for all firms, while Panel B compares ARs and CARs for firms with and without CBDs. To calculate CARs, we use standard event study methodology used in the literature. ARs are calculated using the market model with CRSP value-weighted index. ${ }^{11}$ The parameters are estimated over 120 days where the ending day of the estimation period is 30 days prior to the announcement date.

[Insert Table 5 here]

Both Panels A and B report ARs of $-1,0$, and +1 day and CARs for the windows $(-1,+1)$, $(-2,+2),(-5,+5)$, and $(-10,+10)$, where $t=0$ is the CEO turnover announced date. Panel A shows that forced CEO turnovers are generally considered as negative news in our sample. However, Table 5 Panel B shows that firms with CBDs experience favorable stock market reaction to forced CEO turnover news. For example, the mean (median) CARs $(-1,+1)$ is $-1.14 \%(-0.34 \%)$ for firms without CBDs while CARs for firms with CBDs is $3.52 \%(0.60 \%)$ and the difference of mean (median) CARs is statistically significant. This result supports H3 that CBDs' existence is positively associated with forced CEO turnover news.

Table 5, Panel C presents the summary statistics and test of difference between the firms with and without CBDs for 317 firms that experienced forced CEO turnovers and shows similar results as the overall sample shown in Table 2.

\section{IV.4 Multivariate analysis on forced CEO turnover announcement returns}

To further examine $\mathrm{H} 3$ and investigate $\mathrm{H} 4$, we perform a multivariate analysis with OLS regression using CAR $(-1,+1)$ as our dependent variable. We follow the CEO turnover and corporate governance literature in selecting control variables. We control for firm size ${ }^{12}$, firm performance, idiosyncratic volatility (constructed as in Bushman et al., 2010), book-to-market 
equity and 1 \{CEO outsider succession\} dummy, where the variable equals one when the CEO is succeeded by an outsider. We also include industry and year dummies to control for any possible fixed effects for all models and the standard errors are clustered at firm level. ${ }^{13}$ Due to limited data, we only perform multivariate analyses with fraction of CBDs and do not examine the effect of ABDs. ${ }^{14}$

Regression results in columns (1) - (2) of Table 6 confirm that the market on average reacts positively to forced CEO turnover news when there are more CBDs. ${ }^{15}$ The result is not only statistically significant but also economically significant: with one standard deviation increase in the fraction of CBD (4.5\%), it increases forced CEO turnover announcement effect on stock return by $1.24 \%$ point when the average CAR $(-1,+1)$ is $-0.69 \%$. This finding implies that the CEO dismissal decision is generally more positive to shareholders when there are more CBDs.

\section{[Insert Table 6 here]}

In order to examine $\mathrm{H} 4$, we include interaction terms with performance and director variables on CARs $(-1,+1)$. The results are reported in columns (3) - (8) of Table 6. Only when performance measures are interacted with the fraction of CBD do we see a statistically significant negative sign. Column (5) shows that one standard deviation increase in \%CBD (4.5\%) and one standard deviation lower industry adjusted ROA of $19.2 \%$ would result in $1.7 \%$ point higher investor response on forced CEO turnover announcement. In addition, Column (8) shows that one standard deviation increase in \%CBD (4.5\%) and one standard deviation lower industry adjusted cash flow (2.214) would result in $0.54 \%$ point higher investor response on forced CEO turnover announcement. Considering the unconditional mean of CAR $(-1,+1)$ being $-0.69 \%$, these positive effects of having CBDs is economically significant. Overall, these results support our H3 and H4.

However, when CBD is interacted with risk, as seen in Table 7, we do not find any significant results on forced CEO turnover announcement effect. This may imply that the CBDs' firing decision rule based on firm risk to reduce downside risk is not necessarily value-enhancing for shareholders, supporting Jensen and Meckling (1976).

[Insert Table 7 here] 


\section{IV.5 Post-performance and post-risk analyses}

The post-turnover analysis is based on the same data used for analyzing the forced CEO turnover announcement effect. Figure 1 Panel A shows the industry median adjusted ROA from 4 years prior to 3 years after the CEO turnover year. The group is divided for firms with and without CBDs. Figure 1 shows that both groups' ROA falls rapidly until the CEO turnover year and slightly increases post-CEO-turnover-year. Although post-ROA performance is slightly better in firms with CBDs than ones without CBDs, the difference between the two groups are not statistically different. To examine whether these performance changes meaningfully from year to year by different groups of firms, we perform a difference-in-difference (DID) test and results are shown in Figure 1 Panel B. It shows that firms with CBDs have less and less negative ROA changes after the CEO turnover whereas firms without CBDs have more and more negative ROA changes for the same period. ${ }^{16}$

\section{[Insert Figure 1 here]}

Figure 2 Panel A shows the idiosyncratic risk from 2 years prior to 2 years after the CEO turnover year. It shows that both group's idiosyncratic risk rises slightly before the CEO turnover year and then falls after the CEO dismissal. It also shows that firms with CBDs generally have lower idiosyncratic risk for all time periods, confirming prior literature that bankers tend to sit on less risky firms. Figure 2 Panel B shows the DID test to examine whether these idiosyncratic risk changes year to year depending on whether the firms have CBDs or not. Panel B of Figure 2 shows that firms with CBDs changes idiosyncratic risk more drastically compared to prior-CEOturnover-year than those without CBDs.

[Insert Figure 2 here]

Although univariate analyses on post-performance or post-risk show no statistical significance, we find an interesting pattern: for firms with CBDs, post-performance rises more while post-risk decreases further. The non-statistical difference may be due to unobserved factors. Hence, we perform multivariate analyses.

First, we analyze post-performance with dependent variable being a change in industry median adjusted ROA between the CEO-turnover-year $(\mathrm{t}=0)$ and one year after $(\mathrm{t}=+1)$. The results are presented in Table 8. Columns (2) and (3) of Table 8 indicate that when there are more CBDs, the industry median adjusted ROA increases after 1 year since the CEO turnover year. This result suggests that the existence of CBDs helps firms to revive faster than for firms 
without one, possibly by providing appropriate financial advice and expertise. Moreover, this result is economically significant: the unconditional mean of the industry adjusted ROA before the CEO turnover for this data sample is $0.024 \%$. Having one standard deviation higher percentage of CBD (4.5\%) and one standard deviation lower industry adjusted ROA (19.2\%) before CEO turnover would lead to $4.5 \%$-point increase in industry adjusted ROA one year after the CEO turnover.

\section{[Insert Table 8 here]}

Next, we perform multivariate analyses on post-risk in Table 9. Panel A of Table 9 uses change of idiosyncratic risk performance from CEO turnover year to 1 year after as a dependent variable. In Panel A, columns (1) - (3) include interaction with 1 \{High change of Idio.risk (-2, 1)\}, which represents a dummy variable where the variable equals one if the change of Idiosyncratic risk $(-2,-1)$ is in the $4^{\text {th }}$ quartile and zero otherwise. Columns (4) - (6) use interaction with the level variable of idiosyncratic risk measured at one year prior to the CEO turnover year. We find that with more CBDs, when the change of the idiosyncratic risk was high $^{17}$ between $\mathrm{t}=-2$ and $\mathrm{t}=-1$ or when prior year's idiosyncratic risk was high, then postidiosyncratic risk decreases.

\section{[Insert Table 9 here]}

Likewise, Panel B of Table 9 shows similar result using ROA risk. Columns (1) - (3) uses the change of ROA risk from CEO turnover announced year $(\mathrm{t}=0)$ to one year after $(\mathrm{t}=+1)$, while columns (4) - (6) uses the change of ROA risk from $t=0$ to $t=+2$ as the dependent variable. We find that higher the ROA risk in prior year, the lower the ROA risk one year after the CEO turnover year with more CBDs for both categories of the dependent variables.

Overall, post-turnover analyses suggest that performance increases more for firms with CBDs one year after the CEO is fired when prior year's ROA was inferior, while post-risk decreases when prior year's risk was high for firms with CBDs. Such results infer that CBDs are firing poor-performing CEOs leading to a higher performance after the CEO dismissal. But also post-risk analysis results suggest that CBD-firms are more involved in firing risk-loving CEOs and later leading the newly-appointed CEO to focus on reducing firm risk, an action that may be in conflict with shareholders' interests.

We recognize the concern that CBDs may self-select to sit on certain type of boards. ${ }^{18}$ To address such self-selection concern, we use Heckman's (1979) two-step procedure following 
Kang and Kim (2017) and Kang, Kim, and Liao (2019) in our untabulated analysis. In addition, we employ the propensity score matching procedure to ensure the results are not driven by small outliers and/or by systematic differences between CBD-firms and non-CBD-firms in our untabulated analysis. ${ }^{19}$ We find that our baseline analysis that ABDs are both sensitive to firm performance and firm risk with respect to CEO dismissal is robust.

\section{Conclusion}

CBDs are double edged swords in providing incentives to the CEOs. Having bankers on board brings natural conflict of interest despite the financial expertise they may bring to the table. While Kang and Kim (2017) show that the presence of CBDs makes the explicit incentive of CEO pay become less sensitive to risk, our study shows that the presence of CBDs makes the implicit incentive of CEO turnover become more sensitive to both performance and risk. While the portion of US firms with CBDs is diminishing, it is still high in other countries with 'bank based economic development (Allen and Gale, 2000; Goldsmith, 1969; La Porta, Lopez-de-Silanes, and Shleifer, 2002; Demirgüç-Kunt and Levine, 2004)' as in Europe and Asia (Kroszner and Strahan, 2001; Levine, 2002). Also, this paper that studies the governance effect of CBDs is important because it extends the testing of conflict of interest theory between two different kinds of investors in capital market, the debt-holders and shareholders (Jensen and Meckling, 1976), formerly applied in various aspects of corporate finance, such as capital structure ( Sisli-Ciamarra, 2012), M\&As (Hilscher and Şişli-Ciamarra, 2013), investments

(Guner et al., 2008), R\&D investment (Ghosh, 2016) and accounting conservatism (Erkens et al., 2014).

\section{REFERENCES}

Adams, R., and D. Ferreira, 2009, Women in the boardroom and their impact on governance and performance, Journal of Financial Economics 94(2), pp. 291-309.

Adams, R. B., B. E. Hermalin, and M. S. Weisbach, 2010, The role of boards of directors in corporate governance: A conceptual framework and survey, Journal of Economic Literature 48(1), pp. 58107.

Agrawal, A., and T. Nasser, 2019, Blockholders on Boards and CEO Compensation, Turnover and Firm Valuation, Quarterly Journal of Finance 9(3), pp. 1950010.

Allen, F., and D. Gale, 2000. Comparing financial systems. (MIT press) 
Baker, M., and P. A. Gompers, 2003, The determinants of board structure at the initial public offering, The Journal of law and Economics 46(2), pp. 569-598.

Bonnier, K.-A., and R. F. Bruner, 1989, An analysis of stock price reaction to management change in distressed firms, Journal of Accounting and Economics, 11(1), 95-106.

Booth, J. R., and D. N. Deli, 1999, On executives of financial institutions as outside directors, Journal of Corporate Finance 5(3), pp. 227-250.

Bushman, R., Z. Dai, and X. Wang, 2010, Risk and CEO turnover, Journal of Financial Economics 96 (3), pp. 381-398.

Byrd, D. T., and M. S. Mizruchi, 2005, Bankers on the Board and the Debt Ratio of Firms, Journal of Corporate Finance 11, pp. 129-173.

Dahya, J., J.J. McConnell, and N. G. Travlos, 2002, The Cadbury committee, corporate performance, and top management turnover, The Journal of Finance 57(1), pp. 461-483.

Demirgüç-Kunt, A., and R. Levine, 2004, Financial structure and economic growth: A cross-country comparison of banks, markets, and development. (MIT press)

Diamond, D. W., 1984, Financial intermediation and delegated monitoring, The Review of Economic Studies 5l(3), pp. 393-414.

Dikolli, S. S., W. J. Mayew, and D. Nanda, 2014, CEO tenure and the performance-turnover relation, Review of Accounting Studies 19(1), pp. 281-327.

Dimopoulos, T., and H. F. Wagner, 2016, Corporate Governance and CEO Turnover Decisions, Swiss Finance Institute Research Paper, http://dx.doi.org/10.2139/ssrn.2040690

Dittmann, I., E. Maug, and C. Schneider, 2009, Bankers on the boards of German firms: What they do, what they are worth, and why they are (still) there, Review of Finance 14(1), pp. 35-71.

Erkens, D. H., K. Subramanyam, and J. Zhang, 2014, Affiliated banker on board and conservative accounting, The Accounting Review 89(5), pp. 1703-1728.

Fama, E. F., 1980, Agency problems and the theory of the firm, Journal of Political Economy 88(2), pp. 288-307.

Fama, E. F., 1985, What's different about banks? Journal of Monetary Economics 15(1), pp. 29-39.

Fama, E. F., and M. C. Jensen, 1983, Separation of ownership and control, The Journal of law and Economics 26(2), pp. 301-325.

Fee, C. E., C. J. Hadlock, J. Huang, and J. R. Pierce, 2017, Robust models of CEO turnover: new evidence on relative performance evaluation, Review of Corporate Finance Studies 7(1), pp. 70100.

Furtado, E.P.H., and M.S. Rozeff, 1987, The wealth effects of company initiated management changes, Journal of Financial Economics 18(1), pp. 147-160. 
Ghosh, S., 2016, Banker on board and innovative activity, Journal of Business Research 69(10), pp. 4205-4214.

Gibbons, R., and K. J. Murphy, 1990, Relative performance evaluation for chief executive officers, ILR Review 43(3), pp. 30-S-51-S.

Goldsmith, R. W., 1959, Financial structure and development as a subject for international comparative study, The comparative study of economic growth and structure, NBER, pp. 114-123.

Guner, A. B., U. Malmendier, and G. Tate, 2008, Financial expertise of directors, Journal of Financial Economics 88(2), pp. 323-354.

Hallman, G., J. C. Hartzell, and C. A. Parsons, 2011, Incentive compensation and the likelihood of termination: Theory and evidence from real estate organizations, Real Estate Economics 39(3), pp. 507-546.

Hilscher, J., and E. Şişli-Ciamarra, 2013, Conflicts of interest on corporate boards: The effect of creditordirectors on acquisitions, Journal of Corporate Finance 19, pp. 140-158.

Huang, Q., F. Jiang, E. Lie, and K. Yang, 2014, The role of investment banker directors in M\&A, Journal of Financial Economics 112(2), pp. 269-286.

Huson, M. R., R. Parrino, and L. T. Starks, 2001, Internal monitoring mechanisms and CEO turnover: A long-term perspective, The Journal of Finance 56(6), pp. 2265-2297.

Jensen, M. C., and W. H. Meckling, 1976, Theory of the firm: Managerial behavior, agency costs and ownership structure, Journal of Financial Economics 3(4), pp. 305-360.

Jenter, D., and F. Kanaan, 2015, CEO turnover and relative performance evaluation, The Journal of Finance 70(5), pp. 2155-2184.

John, K., L.Litov, and B. Yeung, 2008, Corporate governance and risk-taking, The Journal of Finance 63(4), pp. 1679-1728.

Kang, J.-K., and A. Shivdasani, 1995, Firm performance, corporate governance, and top executive turnover in Japan, Journal of Financial Economics 38(1), pp. 29-58.

Kang, M. J., and A. Kim, 2017, Bankers on the Board and CEO Incentives, European Financial Management 23(2), pp. 292-324.

Kang, M. J., Y.H.A. Kim, and Q. Liao, 2019, Do bankers on the board reduce crash risk? European Financial Management, pp. 1-40. https://doi.org/10.1111/eufm.12241

Kaplan, S. N., 1994, Top executive rewards and firm performance: A comparison of Japan and the United States, Journal of Political Economy 102(3), pp. 510-546.

Kaplan, S. N., and B. Minton, 2012, How has CEO turnover changed? International Review of Finance 12(1), pp. 57-87. 
Kroszner, R. S., and P. E. Strahan, 2001, Bankers on boards: monitoring, conflicts of interest, and lender liability, Journal of Financial Economics 62(3), pp. 415-452.

Kwon, I., 2005, Threat of dismissal: incentive or sorting? Journal of Labor Economics 23(4), pp. 797-838.

La Porta, R., F. Lopez-de-Silanes, and A. Shleifer, 2002, Government ownership of banks, The Journal of Finance 57(1), pp. 265-301.

Mitchell, K., 2015, Bank dependency and banker directors, Managerial Finance 41(8), pp. 825-844.

Parrino, R., 1997, CEO turnover and outside succession: A cross-sectional analysis, Journal of Financial Economics 46, pp. 165-197.

Peters, F. S., and A. F. Wagner, 2014, The executive turnover risk premium, The Journal of Finance 69(4), pp. 1529-1563.

Sarasvathy, D., H. A. Simon, and L. Lave, 1998, Perceiving and managing business risks: Differences between entrepreneurs and bankers, Journal of Economic Behavior and Organization 33(2), pp. 207-225.

Şişli-Ciamarra, E., 2012, Monitoring by Affiliated Bankers on Board of Directors: Evidence from Corporate Financing Outcomes, Financial management 41(3), pp. 665-702.

Srivastav, A., K. Keasey, S. Mollah, and F. Vallascas, 2017, CEO turnover in large banks: Does tail risk matter? Journal of Accounting and Economics 64(1), pp. 37-55.

Stulz, R. M., 2015, Risk-taking and risk management by banks, Journal of Applied Corporate Finance 27(1), pp. 8-18.

Wang, C., F. Xie, and M. Zhu, 2015, Industry expertise of independent directors and board monitoring. Journal of Financial and Quantitative Analysis 50(5), pp. 929-962.

Warner, J. B., R. L. Watts, and K. H. Wruck, 1988, Stock prices and top management changes, Journal of Financial Economics 20, pp. 461-492.

Weinstein, D. E., and Y. Yafeh, 1998, On the costs of a bank-centered financial system: Evidence from the changing main bank relations in Japan, The Journal of Finance 53(2), pp. 635-672.

Weisbach, M. S., 1988, Outside directors and CEO turnover, Journal of Financial Economics 20, pp. 431-460.

Appendix. Variable definitions (alphabetical order)

1 High CEO ownership\}

Dummy variable, where the value equals 1 when CEO owns more than 5\% of ownership and zero otherwise 


\begin{tabular}{|c|c|}
\hline 1 yr excess stock return & $\begin{array}{l}\text { Annualized daily stock returns subtracted by CRSP value-weighted index } \\
\text { [return-CRSP value weighted index] }\end{array}$ \\
\hline $1\{\mathrm{CBD}\}$ & $\begin{array}{l}\text { Dummy variable, where the value equals } 1 \text { when a firm has a CBD and } \\
\text { zero otherwise }\end{array}$ \\
\hline $1\{$ CEO retirement age $\}$ & $\begin{array}{l}\text { Dummy variable, where the value equals } 1 \text { when CEO age is between } 63 \\
\text { and } 65 \text { years old, and zero otherwise }\end{array}$ \\
\hline 1 Chairman $=$ & $\begin{array}{l}\text { Dummy variable, where the value equals } 1 \text { when CEO is also a chairman } \\
\text { and zero otherwise }\end{array}$ \\
\hline $1\{\mathrm{CEO}$ outsic & $\begin{array}{l}\text { Dummy variable, where the value equals } 1 \text { when successive CEO was an } \\
\text { outsider }\end{array}$ \\
\hline$\% \mathrm{ABD}$ & Fraction of ABDs, following Guner, Malmendier and Tate (2011) \\
\hline$\% \mathrm{CBD}$ & Fraction of CBDs \\
\hline$\% \mathrm{NABD}$ & $\begin{array}{l}\text { Fraction of NABDs, } \\
\text { calculated as \%CBD - \%ABD }\end{array}$ \\
\hline$\%$ Outside Directors & Independent director percentage \\
\hline $\mathrm{BE} / \mathrm{ME}$ & Book-to-market equity, calculated as ceq / (prcc_f $*$ csho $)$ \\
\hline Board memb & The number of directors serving on a firm's board \\
\hline Ln(board si & Natural Log(board size), where board size is the number of board members \\
\hline Cash flow $(C$ & $\begin{array}{l}\text { Defined as } \mathrm{CF} / \mathrm{k} \text {; calculated as } \operatorname{sum}(\mathrm{ib}, \mathrm{dp}) / \text { lagppent; , where lagppent is } \\
\text { lagged PPENT from Compustat data }\end{array}$ \\
\hline Cash flow (in & $\begin{array}{l}\text { A firm's cash flow less the median cash flow in the same industry. } \\
\text { Industry is defined using Fama-French } 49 \text { industry classification }\end{array}$ \\
\hline CEO age & The age of the CEO \\
\hline CEO tenure & $\begin{array}{l}\text { Tenure of a CEO which measures how long a CEO has been working in } \\
\text { that firm }\end{array}$ \\
\hline Idiosyncratic $\mathrm{r}$ & $\begin{array}{l}\text { "Sigma" = RMSE of running a market model using EVENTUS (where } \\
\text { estimation length =256) (but for missing sigma, replaced with RMSE } \\
\text { where estimation.length=20) which follows Bushman et al. (2010) }\end{array}$ \\
\hline KMV ED & KMV Estimated default frequency from Moody's data \\
\hline Firm size & $\begin{array}{l}\text { Natural } \log (\text { total assets }) \text {, where total assets is AT variable from Compustat } \\
\text { data }\end{array}$ \\
\hline MAV_BOARDSIZE_IR & Trailing three-year moving average of board size \\
\hline MAV_CASHAT & Trailing three-year moving average of cash divided by total assets \\
\hline
\end{tabular}




\begin{tabular}{|c|c|}
\hline & $(\# \mathrm{CH} / \# \mathrm{AT})$. \\
\hline$M A V \_K M V E D F$ & Trailing three-year moving average of KMV EDF \\
\hline$M A V \_L A T$ & Trailing three-year moving average of the natural logarithm of total assets . \\
\hline MAV_INSID & $\begin{array}{l}\text { Trailing three-year moving average of the percentage of insiders of board } \\
\text { members. }\end{array}$ \\
\hline$M A V \_N O C R E D I T$ & $\begin{array}{l}\text { Trailing three-year moving average of an indicator variable that is one if } \\
\text { the credit rating is missing, and zero otherwise. }\end{array}$ \\
\hline$M A V_{-} M T B$ & $\begin{array}{l}\text { Trailing three-year moving average of the market value of equity divided } \\
\text { by book value of equity. }\end{array}$ \\
\hline$M A V \_R A$ & $\begin{array}{l}\text { Trailing three-year moving average of the credit rating by S\&P in which } \\
\text { the rating is transformed to numbers: better credit quality takes a higher } \\
\text { number. We assign } 22 \text { to an AAA rating and } 0 \text { to a CCC rating. }\end{array}$ \\
\hline$M A V_{-} R E$ & $\begin{array}{l}\text { Trailing three-year moving average of the standard deviation of daily stock } \\
\text { returns over the fiscal year }\end{array}$ \\
\hline$M A V_{-} R N$ & $\begin{array}{l}\text { Trailing three-year moving average of } \mathrm{R} \& \mathrm{D} \text { expense divided by total } \\
\text { assets }\end{array}$ \\
\hline$M A V_{-} T L T A$ & Trailing three-year moving average of total leverage divided by total assets \\
\hline ROA (ind. & $\begin{array}{l}\text { Industry median adjusted ROA, where } \mathrm{ROA}=\text { oibdp/at (from } \\
\text { COMPUSTAT) }\end{array}$ \\
\hline ROA risk & $\begin{array}{l}\text { An accounting-based risk measure used in Bushman et al. (2010); Standard } \\
\text { deviation of prior } 5 \text { years of quarterly ROA, where ROA is calculated as } \\
\text { oibdpq / atq from fundq table of COMPUSTAT; Before calculating for } \\
\text { standard deviation, industry median is adjusted }\end{array}$ \\
\hline STDEBTRATIO & Short-term debt divided by long-term debt \\
\hline
\end{tabular}




\section{Figure 1. ROA PERFORMANCE BEFORE AND AFTER CEO TURNOVER}

The sample period is 1999-2008. The figures show industry median adjusted ROA graphs before and after the CEO turnover event, where $\mathrm{t}=0$ is the year when the CEO was forced out. The dotted values are average values.

Panel A. ROA around CEO turnover

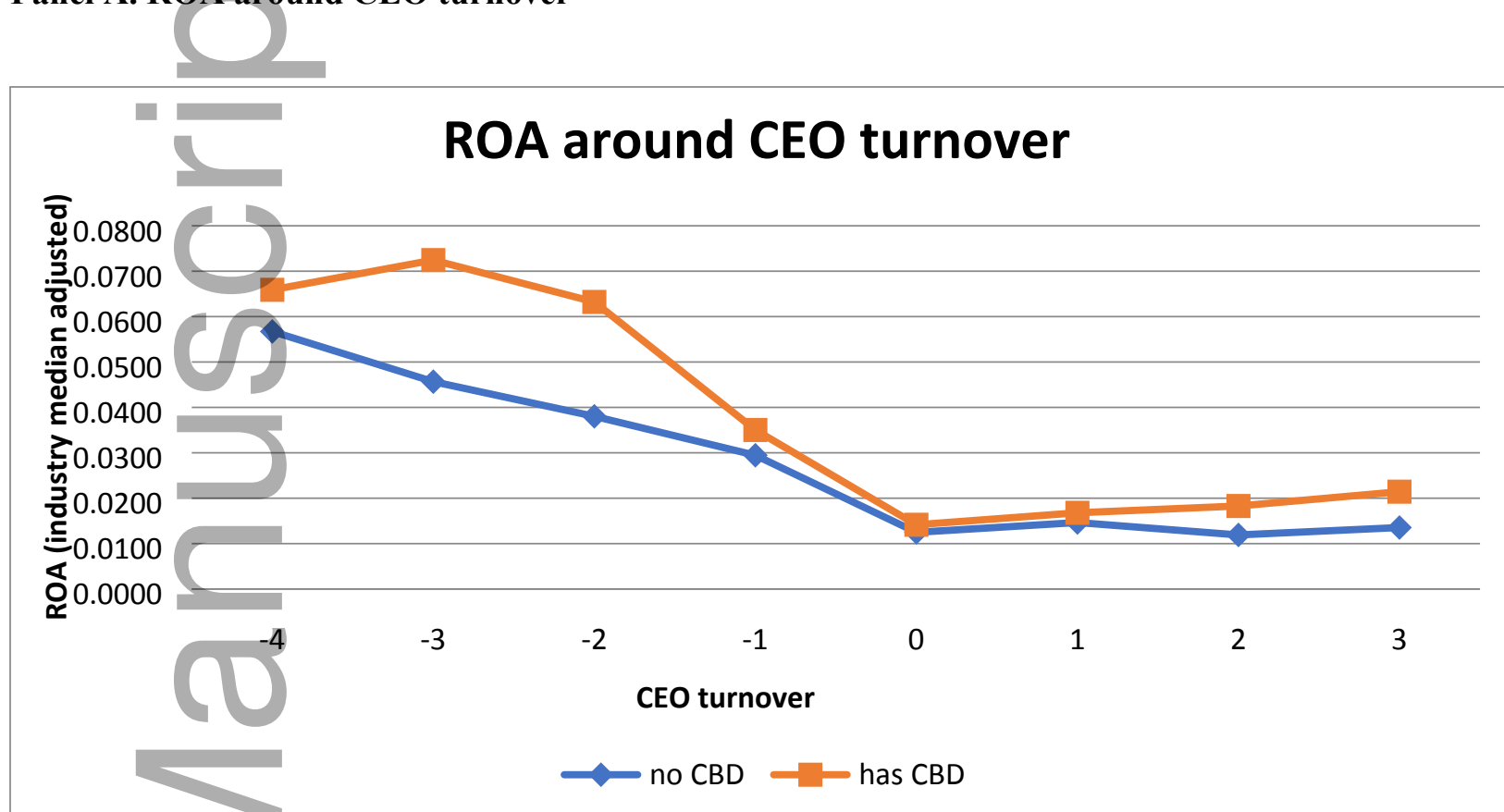

Panel B. Difference in Difference (DID) of ROA around CEO turnover






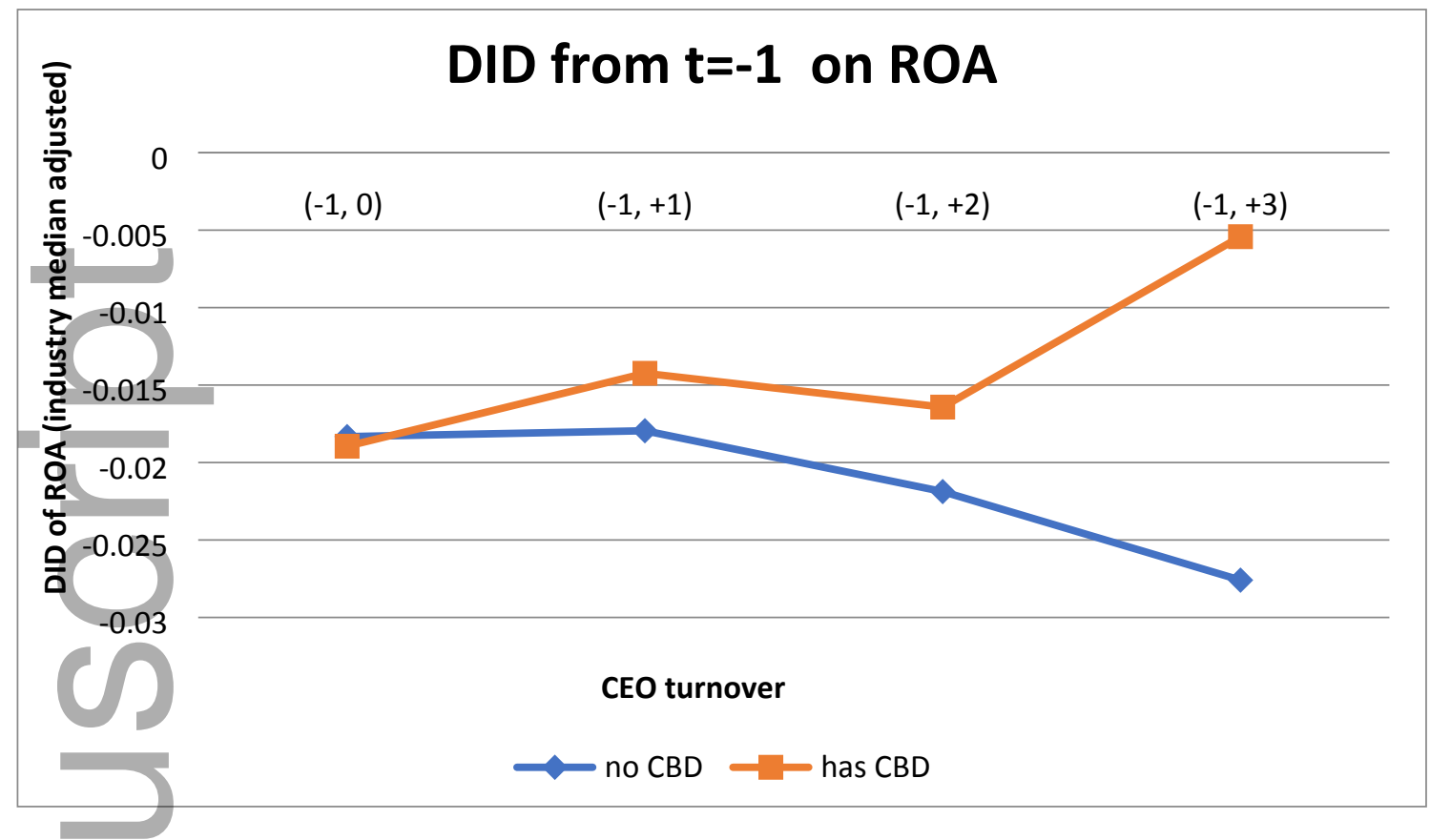

Figure 2. IDIOSYNCRATIC RISK BEFORE AND AFTER CEO TURNOVER

The sample period is 1999-2008. The figures show idiosyncratic risk graphs before and after the CEO turnover event, where $\mathrm{t}=0$ is the year when the CEO was forced out.

Panel A. Idiosyncratic risk around CEO turnover

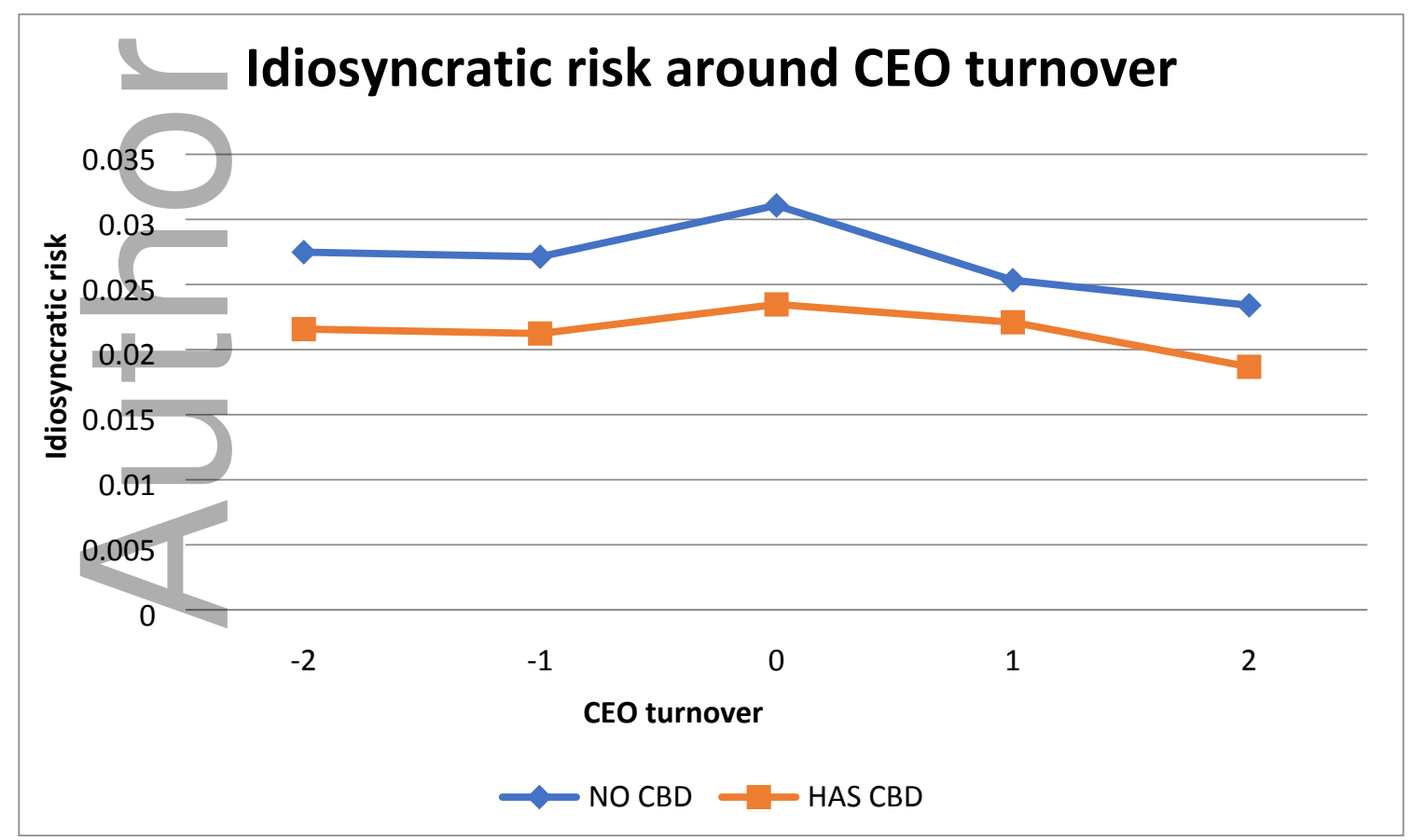

This article is protected by copyright. All rights reserved 
Panel B. Difference in Difference (DID) of idiosyncratic risk around CEO turnover

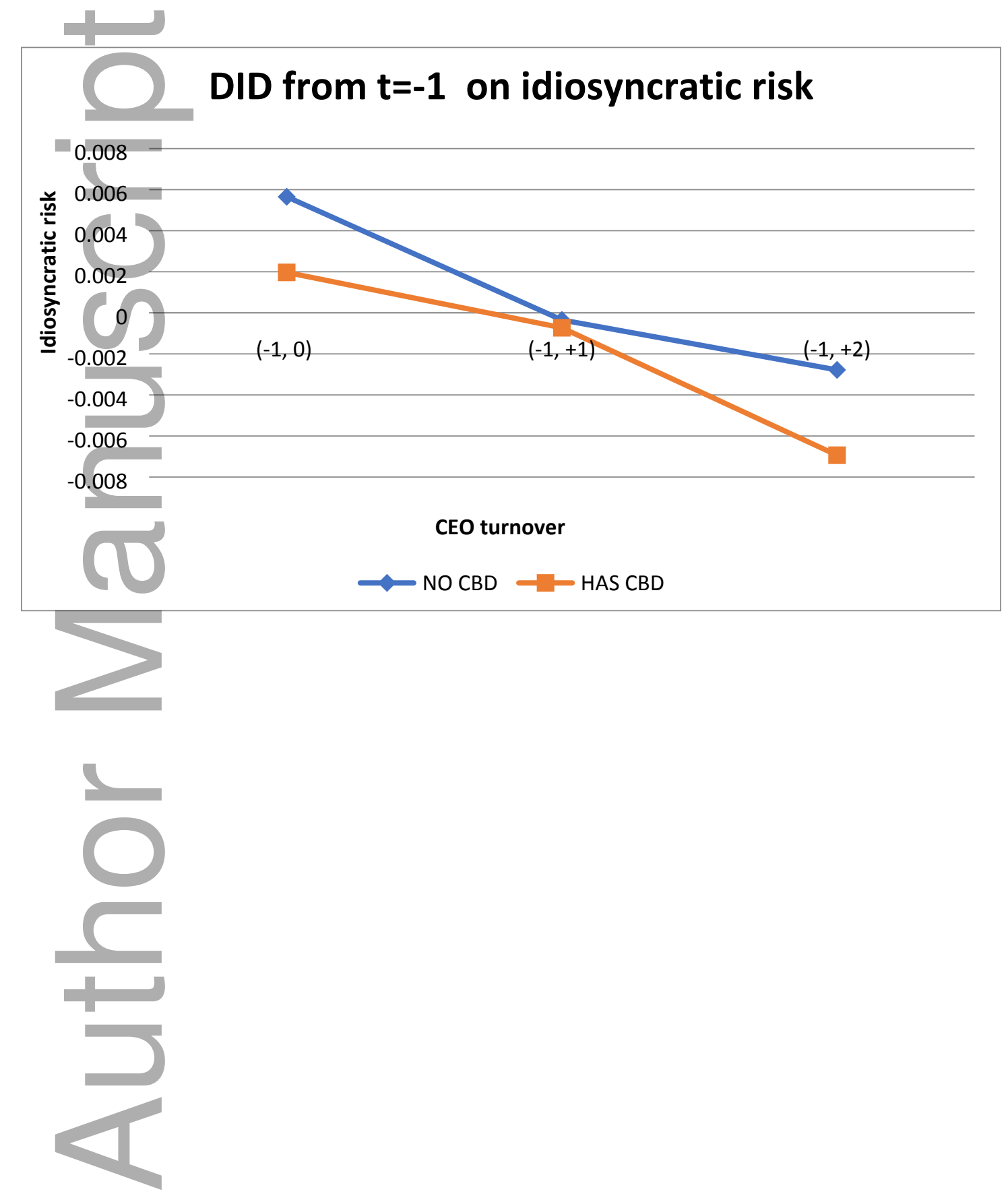

This article is protected by copyright. All rights reserved 
Table 1. Sample distribution by year, industry, and number of firms with banker directors

The sample period is 1999-2008. Firm-years in our sample is an intersection of Execucomp, Boardex, Compustat and Crsp. The sample consists of 12,608 firmyears, of which 1,180 have commercial banker directors (CBDs) in their firm boards. We use the Boardex data to identify banker directors on board. Industry classifications are based on the two-digit SIC code. The numbers in the parentheses are firms with at least one banker director on their boards.

\begin{tabular}{|c|c|c|c|c|c|c|c|c|c|c|c|c|c|c|c|c|c|}
\hline \multirow[t]{2}{*}{$\begin{array}{l}\text { Year } \\
\text { Yer } \\
1999\end{array}$} & \multirow[t]{2}{*}{$\begin{array}{l}\text { Agriculture, } \\
\text { Forestry, } \\
\text { And } \\
\text { Fishing } \\
0 \quad(0)\end{array}$} & Mining & Construction & Manufacturing & \multicolumn{2}{|c|}{$\begin{array}{l}\text { Transportation, } \\
\text { Communications, } \\
\text { Electric, Gas, } \\
\text { And Sanitary } \\
\text { Services }\end{array}$} & \multicolumn{2}{|c|}{$\begin{array}{c}\text { Wholesale } \\
\text { Trade }\end{array}$} & \multicolumn{2}{|c|}{ Retail Trade } & $\begin{array}{c}\text { Finance, } \\
\text { Insurance, } \\
\text { And Real } \\
\text { Estate }\end{array}$ & \multicolumn{2}{|c|}{ Services } & \multicolumn{2}{|c|}{$\begin{array}{c}\text { Public } \\
\text { Administration }\end{array}$} & \multicolumn{2}{|c|}{ Total } \\
\hline & & $\begin{array}{ll}3 & (1)\end{array}$ & (6) & (3) & 9 & (3) & 17 & (3) & 18 & (3) & $17 \quad(1)$ & 2 & (0) & 2 & (1) & 130 & (21) \\
\hline 2000 & $4(0)$ & $53 \quad(3)$ & $(25)$ & $(25)$ & 123 & (26) & 143 & (18) & 172 & (18) & 120 & 36 & (3) & 3 & (1) & 1,116 & (131) \\
\hline 2001 & 5 & $62 \quad(4)$ & (28) & $(27)$ & 132 & (31) & 155 & (18) & 198 & (18) & 141 & 43 & (3) & 5 & (1) & 1,277 & (138) \\
\hline 2002 & 0) & $63 \quad(6)$ & $(31)$ & $(26)$ & 134 & (26) & 151 & (19) & 195 & (17) & 141 & 45 & (3) & 5 & (1) & 1,279 & (139) \\
\hline 2003 & $5 \quad(1)$ & $75 \quad(2)$ & (33) & $(23)$ & 154 & (36) & 192 & $(21)$ & 238 & $(25)$ & $180 \quad(11)$ & 58 & (4) & 6 & (1) & 1,565 & $(157)$ \\
\hline 2004 & $6 \quad(1)$ & $82 \quad(4)$ & $(34)$ & $(18)$ & 160 & (29) & 186 & (16) & 241 & $(31)$ & $184 \quad(9)$ & 58 & (1) & 6 & (1) & 1,605 & (144) \\
\hline 2005 & (1) & $80 \quad(3)$ & 241 & $(15)$ & 157 & $(25)$ & 182 & (16) & 248 & $(23)$ & 174 & 58 & $(0)$ & 5 & (1) & 1,574 & $(122)$ \\
\hline 2006 & (0) & $84 \quad(3)$ & $247 \quad(29)$ & $(20)$ & 164 & (26) & 187 & (18) & 285 & $(27)$ & $174 \quad(7)$ & 65 & (2) & 5 & (1) & 1,656 & (133) \\
\hline 2007 & (0) & $88 \quad(5)$ & 240 & (19) & 154 & (24) & 188 & $(16)$ & 288 & $(25)$ & $172 \quad(6)$ & 62 & (2) & 4 & $(0)$ & 1,615 & $(123)$ \\
\hline 2008 & & $47 \quad(2)$ & $(15)$ & (16) & 90 & (17) & 53 & (4) & 139 & $(10)$ & $75 \quad$ (7) & 30 & (1) & 3 & $(0)$ & 791 & (72) \\
\hline Total & 41 & $637(33)$ & $1,926 \quad(257)$ & $3,372 \quad(192)$ & 1,277 & $(243)$ & 1,454 & (149) & 2,022 & (197) & $1,378(79)$ & 457 & (19) & 44 & (8) & 12,608 & $(1,180)$ \\
\hline
\end{tabular}

This article is protected by copyright. All rights reserved 


\section{Table 2. Summary statistics}

The sample period is 1999-2008. The sample consists of 12,608 firm-years, 1,180 of which have banker directors on their firm board. All continuous variables are winsorized at $1 \%$ and $99 \%$ level. *, **, and *** denote significance levels at the $10 \%, 5 \%$, and $1 \%$, respectively. Variable descriptions are in the Appendix.

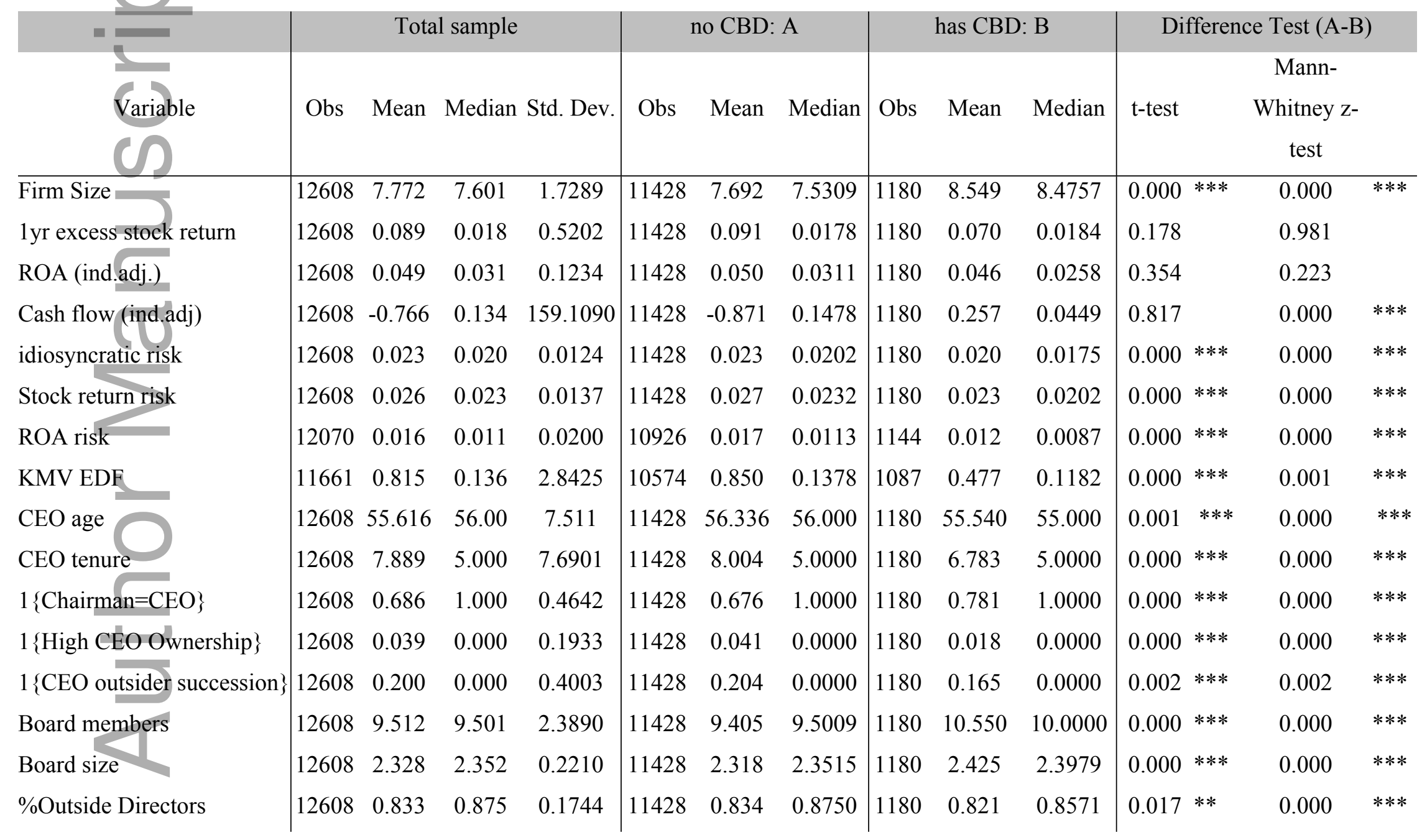

This article is protected by copyright. All rights reserved 


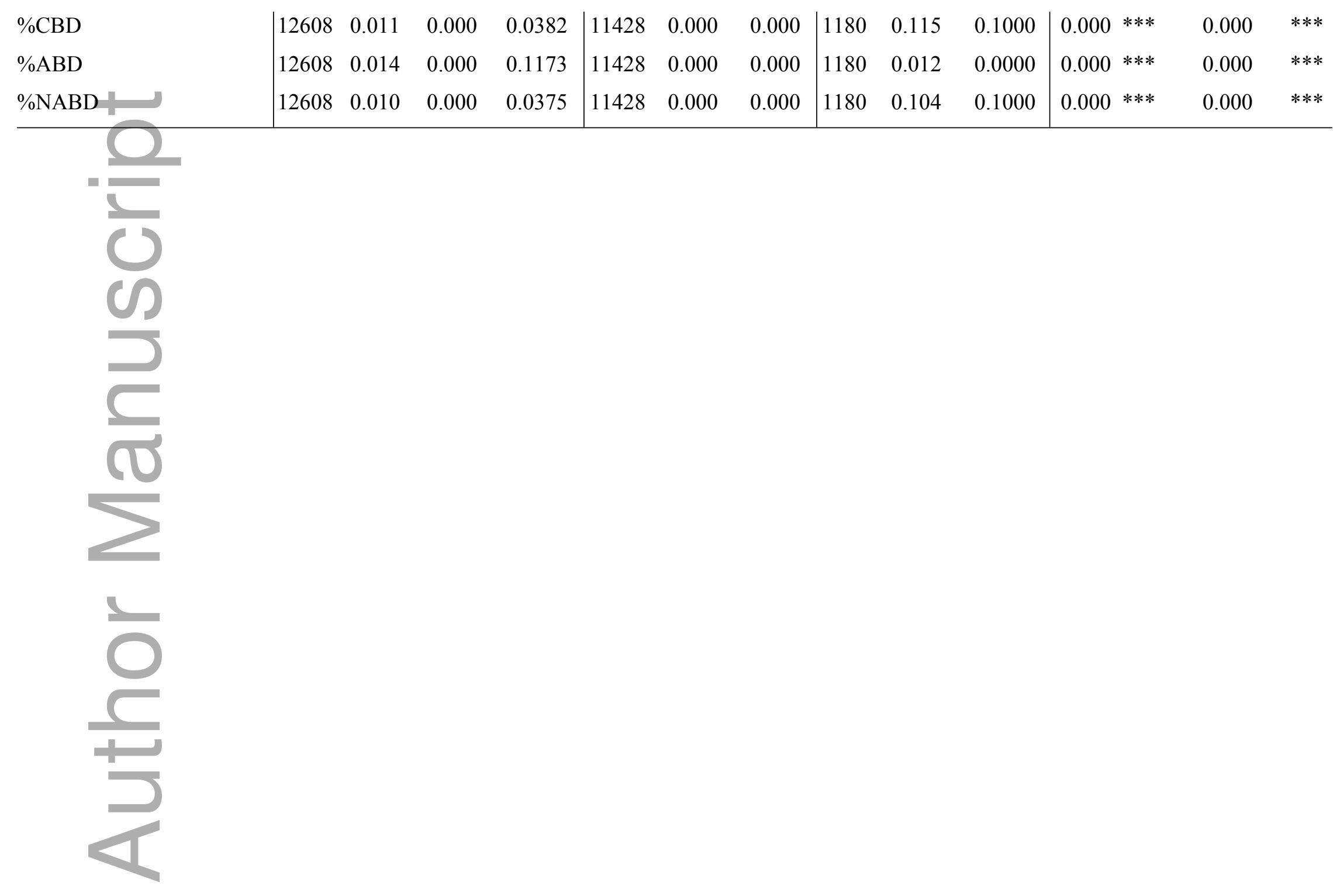

This article is protected by copyright. All rights reserved 


\section{Table 3. CEO turnover and Performance}

The sample period is 1999-2008. The dependent variable is forced turnover, defined as one if there is a forced turnover and zero otherwise. Logit regressions are performed. Industry (four-digit SIC code) and year dummies are included in all specifications. Independent and control variables are lagged by one year. ${ }^{*},{ }^{* *}$, and $* * *$ indicate the significance at the $10 \%, 5 \%$, and $1 \%$ level, respectively. Standard errors are clustered at the firm level. P-values based on heteroscedasticity robust standard errors are in every second line. Control variables are defined in the Appendix.

\begin{tabular}{|c|c|c|c|c|}
\hline Dep. Variable: 1 \{forced CEO turnover\} & (1) & (2) & (3) & (4) \\
\hline \multirow[t]{2}{*}{ \%Outside Directors } & -0.128 & -0.154 & -0.107 & -0.139 \\
\hline & 0.730 & 0.678 & 0.773 & 0.708 \\
\hline \multirow[t]{2}{*}{$\% \mathrm{CBD}$} & & 1.616 & & \\
\hline & & 0.303 & & \\
\hline \multirow[t]{2}{*}{$\% \mathrm{ABD}$} & & & $-19.578^{*}$ & $-19.686^{* *}$ \\
\hline & & & 0.051 & 0.049 \\
\hline \multirow[t]{2}{*}{$\% \mathrm{NABD}$} & & & & 2.049 \\
\hline & & & & 0.200 \\
\hline \multirow[t]{2}{*}{ ROA(ind.adj.)*\%Outside Directors } & 0.741 & 0.712 & 0.691 & 0.688 \\
\hline & 0.661 & 0.673 & 0.684 & 0.684 \\
\hline \multirow[t]{2}{*}{ ROA(ind.adj.)*\%CBD } & & 0.060 & & \\
\hline & & 0.997 & & \\
\hline \multirow[t]{2}{*}{ ROA(ind.adj.)*\%ABD } & & & $-241.863^{* * *}$ & $-243.472 * * *$ \\
\hline & & & 0.000 & 0.000 \\
\hline \multirow{2}{*}{ ROA(ind.adj.)*\%/NABD } & & & & 1.593 \\
\hline & & & & 0.918 \\
\hline \multirow{2}{*}{ ROA(ind.adj.) } & $-0.934 * *$ & $-0.928 * *$ & $-0.921 * *$ & $-0.926 * *$ \\
\hline & 0.021 & 0.022 & 0.023 & 0.023 \\
\hline \multirow[t]{2}{*}{ idiosyncratic risk } & $19.197 * * *$ & $19.238 * * *$ & $19.069 * * *$ & $19.083 * * *$ \\
\hline & 0.000 & 0.000 & 0.000 & 0.000 \\
\hline \multirow[t]{2}{*}{ Firm Size } & 0.041 & 0.039 & 0.043 & 0.042 \\
\hline & 0.365 & 0.387 & 0.340 & 0.360 \\
\hline \multirow[t]{2}{*}{$1\{$ CEO retirement age $\}$} & $-0.872 * * *$ & $-0.872 * * *$ & $-0.871 * * *$ & $-0.871 * * *$ \\
\hline & 0.009 & 0.010 & 0.010 & 0.010 \\
\hline CEO tenure & $-0.042 * * *$ & $-0.042 * * *$ & $-0.043 * * *$ & $-0.042 * * *$ \\
\hline
\end{tabular}




\begin{tabular}{lcccc} 
& 0.000 & 0.000 & 0.000 & 0.000 \\
$1\{$ Chairman=CEO\} & $-0.354 * * *$ & $-0.357^{* * *}$ & $-0.351 * * *$ & $-0.353^{* * *}$ \\
& 0.004 & 0.004 & 0.004 & 0.004 \\
$1\{$ High CEO Ownership\} & -0.065 & -0.075 & -0.073 & -0.085 \\
& 0.860 & 0.841 & 0.845 & 0.819 \\
constant & $-16.007 * * *$ & $-15.983 * * *$ & $-15.277 * * *$ & $-16.376^{* * *}$ \\
& 0.000 & 0.000 & 0.000 & 0.000 \\
Year FE & Yes & Yes & Yes & Yes \\
Industry FE & Yes & Yes & Yes & Yes \\
\hline $\mathrm{N}$ & 12246 & 12246 & 12246 & 12246 \\
Pseudo.R2 & 0.056 & 0.056 & 0.057 & 0.058 \\
\hline
\end{tabular}

\section{Table 4. CEO turnover and Risk}

The sample period is 1999-2008. The dependent variable is forced turnover, defined as one if there is a forced turnover and zero otherwise. Logit regressions are performed. Industry (four-digit SIC code) and year dummies are included in all specifications. Independent and control variables are lagged by one year. As a risk measure, Panel A uses idiosyncratic risk, Panel B uses stock return risk, and Panel C uses ROA risk. Column (5) in Panel A shows the average marginal effects of column (4) regression. *, **, and *** indicate the significance at the $10 \%, 5 \%$, and $1 \%$ level, respectively. Standard errors are clustered at the firm level. P-values based on heteroscedasticity robust standard errors are in every second line. Control variables are defined in the Appendix.

Panel A. Interaction with idiosyncratic risk measure

\begin{tabular}{|c|c|c|c|c|c|}
\hline Dep. Variable: 1 fforced CEO turnover\} & (1) & (2) & (3) & (4) & $\begin{array}{r}(5) \\
d y / d x\end{array}$ \\
\hline \multirow{2}{*}{ \%Outside Directors } & -0.121 & -0.148 & -0.107 & -0.138 & -0.004 \\
\hline & 0.746 & 0.691 & 0.774 & 0.710 & 0.711 \\
\hline \multirow[t]{2}{*}{$\% \mathrm{CBD}$} & & 1.236 & & & \\
\hline & & 0.551 & & & \\
\hline \multirow[t]{2}{*}{$\% A B D$} & & & $-70.341 * * *$ & $-69.483 * * *$ & $-1.778 * * *$ \\
\hline & & & 0.000 & 0.000 & 0.000 \\
\hline \multirow[t]{2}{*}{$\%$ NABD } & & & & 2.513 & 0.064 \\
\hline & & & & 0.243 & 0.242 \\
\hline
\end{tabular}




\begin{tabular}{|c|c|c|c|c|c|}
\hline \multirow[t]{2}{*}{ idiosyncratic risk*\%Outside Directors } & -21.516 & -20.945 & -19.526 & -18.480 & -0.473 \\
\hline & 0.596 & 0.606 & 0.629 & 0.647 & 0.647 \\
\hline \multirow[t]{2}{*}{ idiosyncratic risk $* \%$ CBD } & & 14.289 & & & \\
\hline & & 0.823 & & & \\
\hline \multirow[t]{2}{*}{ idiosyncratic risk*\% $\%$ ABD } & & & $2,200.119 * * *$ & $2,188.475 * * *$ & $56.006 * * *$ \\
\hline & & & 0.000 & 0.000 & 0.000 \\
\hline \multirow{2}{*}{ idiosyncratic risk*\%NABD } & & & & -14.379 & -0.368 \\
\hline & & & & 0.833 & 0.833 \\
\hline \multirow{2}{*}{ ROA(ind.adj.) } & $-0.891 * * *$ & $-0.889 * * *$ & $-0.892 * * *$ & $-0.885 * * *$ & $-0.023 * * *$ \\
\hline & 0.001 & 0.001 & 0.001 & 0.001 & 0.001 \\
\hline \multirow{2}{*}{ idiosyncratic risk } & $19.382 * * *$ & $19.299 * * *$ & $19.108 * * *$ & $19.237 * * *$ & $0.492 * * *$ \\
\hline & 0.000 & 0.000 & 0.000 & 0.000 & 0.000 \\
\hline \multirow[t]{2}{*}{ Firm Size } & 0.042 & 0.040 & 0.043 & 0.041 & 0.001 \\
\hline & 0.358 & 0.377 & 0.337 & 0.362 & 0.361 \\
\hline \multirow{2}{*}{$1\{$ CEO retirement age $\}$} & $-0.872 * * *$ & $-0.873 * * *$ & $-0.888 * * *$ & $-0.888 * * *$ & $-0.023 * * *$ \\
\hline & 0.009 & 0.009 & 0.008 & 0.008 & 0.009 \\
\hline \multirow[t]{2}{*}{ CEO tenure } & $-0.042 * * *$ & $-0.042 * * *$ & $-0.043 * * *$ & $-0.042 * * *$ & $-0.001 * * *$ \\
\hline & 0.000 & 0.000 & 0.000 & 0.000 & 0.000 \\
\hline \multirow{2}{*}{$1\{$ Chairman=CEO $\}$} & $-0.353 * * *$ & $-0.356 * * *$ & $-0.347 * * *$ & $-0.349 * * *$ & $-0.009 * * *$ \\
\hline & 0.004 & 0.004 & 0.005 & 0.005 & 0.005 \\
\hline \multirow{2}{*}{$1\{$ High CEO Ownership $\}$} & -0.062 & -0.071 & -0.057 & -0.071 & -0.002 \\
\hline & 0.866 & 0.848 & 0.877 & 0.849 & 0.849 \\
\hline \multirow[t]{2}{*}{ constant } & $-16.891 * * *$ & $-16.867 * * *$ & $-15.149 * * *$ & $-15.123 * * *$ & \\
\hline & 0.000 & 0.000 & 0.000 & 0.000 & \\
\hline Year FE & Yes & Yes & Yes & Yes & Yes \\
\hline Industry FE & Yes & Yes & Yes & Yes & Yes \\
\hline $\bar{N}$ & 12246 & 12246 & 12246 & 12246 & 12246 \\
\hline Pseudo.R2 & 0.056 & 0.056 & 0.058 & 0.058 & \\
\hline
\end{tabular}

Panel B. Interaction with stock return risk measure

\begin{tabular}{lrrrr}
\hline Dep. Variable: 1 fforced CEO turnover\} & $(1)$ & $(2)$ & $(3)$ & $(4)$ \\
\hline \%Outside Directors & -0.101 & -0.136 & -0.088 & -0.127 \\
& 0.783 & 0.710 & 0.810 & 0.729
\end{tabular}

This article is protected by copyright. All rights reserved 


\begin{tabular}{|c|c|c|c|c|}
\hline \multirow[t]{2}{*}{$\% \mathrm{CBD}$} & \multicolumn{2}{|r|}{-1.289} & & \\
\hline & \multicolumn{2}{|r|}{0.647} & & \\
\hline \multirow[t]{2}{*}{$\% \mathrm{ABD}$} & & & $-48.474 * * *$ & $-48.469 * * *$ \\
\hline & & & 0.000 & 0.000 \\
\hline \multirow[t]{2}{*}{$\% \mathrm{NABD}$} & & & & 0.080 \\
\hline & & & & 0.978 \\
\hline \multirow{2}{*}{ Stock return risk $* \%$ Outside Directors } & -14.290 & -13.450 & -12.487 & -11.310 \\
\hline & 0.695 & 0.711 & 0.730 & 0.754 \\
\hline \multirow[t]{2}{*}{ Stock return risk $* 0 \mathrm{CBD}$} & & 113.368 & & \\
\hline & & 0.187 & & \\
\hline \multirow[t]{2}{*}{ Stock return risk $\%$ ABD } & & & $1,275.911 * * *$ & $1,282.953 * * *$ \\
\hline & & & 0.000 & 0.000 \\
\hline \multirow[t]{2}{*}{ Stock return risk $* \% \mathrm{NABD}$} & & & & 82.786 \\
\hline & & & & 0.357 \\
\hline \multirow{2}{*}{1 yr excess stock return } & $-1.185 * * *$ & $-1.185^{* * *}$ & $-1.188 * * *$ & $-1.188 * * *$ \\
\hline & 0.000 & 0.000 & 0.000 & 0.000 \\
\hline \multirow[t]{2}{*}{ Stock return risk } & $18.553 * * *$ & $18.308 * * *$ & $18.266^{* * *}$ & $18.182 * * *$ \\
\hline & 0.000 & 0.000 & 0.000 & 0.000 \\
\hline \multirow[t]{2}{*}{ Firm Size } & 0.018 & 0.019 & 0.020 & 0.020 \\
\hline & 0.689 & 0.679 & 0.665 & 0.663 \\
\hline \multirow{2}{*}{$1\{\mathrm{CEO}$ retirement age $\}$} & $-0.837 * *$ & $-0.840 * *$ & $-0.852^{* *}$ & $-0.854 * *$ \\
\hline & 0.013 & 0.013 & 0.012 & 0.012 \\
\hline \multirow[t]{2}{*}{ CEO tenure } & $-0.045 * * *$ & $-0.045^{* * *}$ & $-0.046 * * *$ & $-0.045 * * *$ \\
\hline & 0.000 & 0.000 & 0.000 & 0.000 \\
\hline \multirow{2}{*}{$1\{$ Chairman $=\mathrm{CEO}\}$} & $-0.390 * * *$ & $-0.397 * * *$ & $-0.384 * * *$ & $-0.391 * * *$ \\
\hline & 0.002 & 0.001 & 0.002 & 0.002 \\
\hline & -0.099 & -0.107 & -0.098 & -0.110 \\
\hline & 0.787 & 0.770 & 0.790 & 0.765 \\
\hline \multirow[t]{2}{*}{ constant } & $-16.636^{* * *}$ & $-15.872 * * *$ & $-16.266^{* * *}$ & $-15.998 * * *$ \\
\hline & 0.000 & 0.000 & 0.000 & 0.000 \\
\hline Year FE & Yes & Yes & Yes & Yes \\
\hline Industry FE & Yes & Yes & Yes & Yes \\
\hline$\overline{\mathrm{N}}$ & 12246 & 12246 & 12246 & 12246 \\
\hline Pseudo.R2 & 0.075 & 0.076 & 0.076 & 0.077 \\
\hline
\end{tabular}

This article is protected by copyright. All rights reserved 
Panel C. Interaction with ROA risk measure

\begin{tabular}{|c|c|c|c|c|}
\hline Dep. Variable: 1 \{forced CEO turnover\} & (1) & (2) & (3) & (4) \\
\hline \multirow[t]{2}{*}{ \%Outside Directors } & -0.224 & -0.246 & -0.201 & -0.230 \\
\hline & 0.556 & 0.518 & 0.597 & 0.546 \\
\hline \multirow[t]{2}{*}{$\% \mathrm{CBD}=$} & & 0.215 & & \\
\hline & & 0.895 & & \\
\hline \multirow[t]{2}{*}{$\% \mathrm{ABD}$} & & & $-39.774 * * *$ & $-40.051^{* * *}$ \\
\hline & & & 0.000 & 0.000 \\
\hline \multirow[t]{2}{*}{$\% \mathrm{NABD}$} & & & & 0.781 \\
\hline & & & & 0.635 \\
\hline \multirow{2}{*}{ ROA risk*\%Outside Directors } & $-40.336^{* *}$ & $-38.835 * *$ & $-39.930 * *$ & $-38.251^{* *}$ \\
\hline & 0.026 & 0.033 & 0.028 & 0.036 \\
\hline \multirow[t]{2}{*}{ ROA risk*\%CBD } & & $54.859^{* * *}$ & & \\
\hline & & 0.005 & & \\
\hline \multirow[t]{2}{*}{ ROA risk $\% \mathrm{ABD}$} & & & $1,607.156^{* * *}$ & $1,628.732 * * *$ \\
\hline & & & 0.001 & 0.001 \\
\hline \multirow{2}{*}{ ROA risk*\%NABD } & & & & $51.454^{* * *}$ \\
\hline & & & & 0.009 \\
\hline \multirow[t]{2}{*}{ ROA(ind.adj.) } & $-1.321 * * *$ & $-1.408 * * *$ & $-1.333^{* * *}$ & $-1.415^{* * *}$ \\
\hline & 0.000 & 0.000 & 0.000 & 0.000 \\
\hline \multirow[t]{2}{*}{ ROA risk } & $3.411 *$ & 1.611 & 3.301 & 1.555 \\
\hline & 0.092 & 0.382 & 0.108 & 0.402 \\
\hline \multirow{2}{*}{ Firm Size } & -0.002 & -0.006 & 0.000 & -0.004 \\
\hline & 0.968 & 0.887 & 0.992 & 0.926 \\
\hline \multirow[t]{2}{*}{$1\{$ CEO retirement age $\}$} & $-0.882 * * *$ & $-0.883 * * *$ & $-0.884 * * *$ & $-0.886^{* * *}$ \\
\hline & 0.010 & 0.009 & 0.010 & 0.009 \\
\hline \multirow[t]{2}{*}{ CEO tenure } & $-0.044 * * *$ & $-0.044 * * *$ & $-0.045^{* * *}$ & $-0.044 * * *$ \\
\hline & 0.000 & 0.000 & 0.000 & 0.000 \\
\hline \multirow[t]{2}{*}{$1\{$ Chairman $=\mathrm{CEO}\}$} & $-0.403^{* * *}$ & $-0.404 * * *$ & $-0.399 * * *$ & $-0.399 * * *$ \\
\hline & 0.001 & 0.001 & 0.001 & 0.001 \\
\hline $1\{$ High CEO Ownership $\}$ & -0.038 & -0.042 & -0.032 & -0.039 \\
\hline
\end{tabular}

This article is protected by copyright. All rights reserved 


\begin{tabular}{lcccc} 
& 0.919 & 0.912 & 0.932 & 0.917 \\
constant & $-15.430^{* * *}$ & $-15.834^{* * *}$ & $-14.703^{* * *}$ & $-16.354^{* * *}$ \\
Year FE & 0.000 & 0.000 & 0.000 & 0.000 \\
Industry FE & Yes & Yes & Yes & Yes \\
\hline $\mathrm{N}$ & Yes & Yes & Yes & Yes \\
Pseudo.R2 & 11665 & 11665 & 11665 & 11665 \\
\hline
\end{tabular}

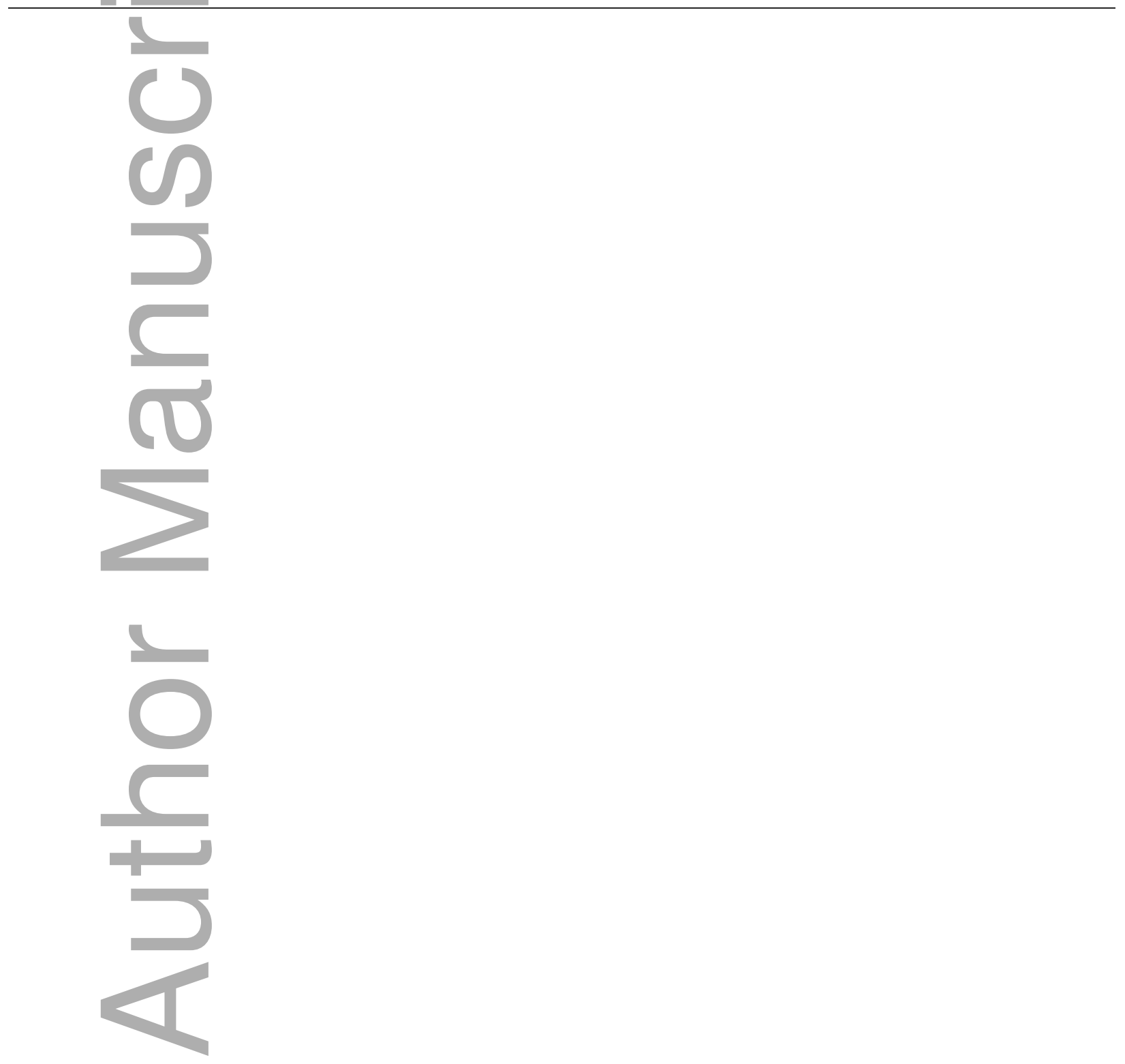




\section{Table 5. Univariate tests: Cumulative Abnormal Returns (CARs) around forced turnover announcement date}

The sample period is 1999-2008. To calculate for the abnormal returns (ARs) and cumulative abnormal returns (CARs), we use the standard event study methodology used in the literature. Abnormal returns are calculated using the market model with CRSP value-weighted index. The parameters are estimated over 120 days where ending day of the estimation period is 30 days prior to the announcement, where $\mathrm{t}=0$ is the CEO turnover announced date. Panel A reports Ars and CARs for all forced CEO turnover announcement news. Panel B reports ARs and CARs for firms with and without CBDs. *, **, and *** indicate the significance at the $10 \%, 5 \%$, and $1 \%$ levels, respectively. Test of difference shows p-value.

Panel A. ARs and CARs for all firms

\begin{tabular}{|c|c|c|c|c|c|c|c|c|}
\hline 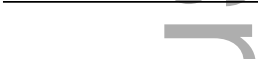 & Obs & Mean & Median & T-tes & & Patell Test & BMP Test & Sign-rank statistics \\
\hline $\operatorname{AR}(-1)$ & 317 & $0.16 \%$ & $-0.04 \%$ & 0.2442 & & 0.1741 & 0.2296 & 0.4629 \\
\hline $\mathrm{AR}(0)$ & 317 & $-0.45 \%$ & $-0.27 \%$ & 0.1086 & & $0.0000 * * *$ & $0.0466 * *$ & $0.0720 *$ \\
\hline $\operatorname{AR}(+1)$ & 317 & $-0.40 \%$ & $-0.24 \%$ & 0.1544 & & $0.0223 * *$ & 0.1930 & $0.0939 *$ \\
\hline $\operatorname{CAR}(-1,+1)$ & 317 & $-0.69 \%$ & $-0.27 \%$ & 0.1311 & & $0.0005 * * *$ & $0.0715 *$ & 0.1465 \\
\hline $\operatorname{CAR}(-2,+2)$ & 317 & $-1.04 \%$ & $-0.44 \%$ & 0.0612 & $*$ & $0.0002 * * *$ & $0.0324 * *$ & $0.0617 *$ \\
\hline $\operatorname{CAR}(-5,+5)$ & 317 & $-1.38 \%$ & $-0.70 \%$ & 0.0714 & $*$ & $0.0001 * * *$ & $0.0104 * *$ & $0.0533 *$ \\
\hline CAR $(-10,+10)$ & 317 & $-1.56 \%$ & $-1.83 \%$ & 0.0980 & $*$ & $0.0000 * * *$ & $0.0068 * * *$ & $0.0178 * *$ \\
\hline
\end{tabular}

Panel B. ARs and CARs for firms with and without CBD

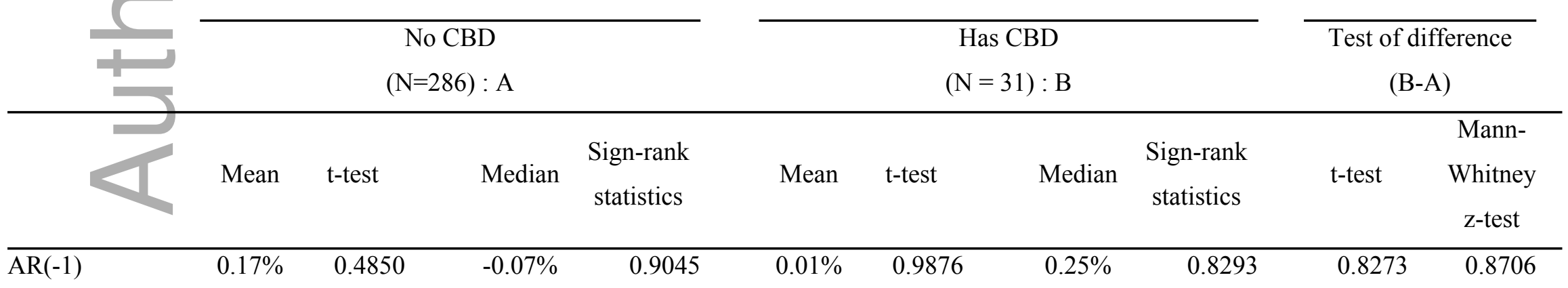

This article is protected by copyright. All rights reserved 


\begin{tabular}{|c|c|c|c|c|c|c|c|c|c|c|}
\hline $\mathrm{AR}(0)$ & $-0.59 \%$ & 0.1295 & $-0.33 \%$ & $0.0553 *$ & $0.82 \%$ & 0.4542 & $0.21 \%$ & 0.2811 & 0.2533 & $0.0950^{*}$ \\
\hline $\operatorname{AR}(+1)$ & $-0.73 \%$ & $0.0680^{*}$ & $-0.28 \%$ & $0.0518^{*}$ & $2.69 \%$ & $0.0825^{*}$ & $0.17 \%$ & $0.0811^{*}$ & $0.0096^{* * *}$ & $0.0212 * *$ \\
\hline CAR $(-1,+1)$ & $-1.14 \%$ & $0.0829 *$ & $-0.34 \%$ & $0.0931 *$ & $3.52 \%$ & $0.0295 * *$ & $0.60 \%$ & $0.0745^{*}$ & $0.0250 * *$ & $0.0277 * *$ \\
\hline $\operatorname{CAR}(-5,+5)$ & $-1.84 \%$ & $0.0746^{*}$ & $-0.87 \%$ & $0.0276^{* *}$ & $2.90 \%$ & $0.0400 * *$ & $2.43 \%$ & $0.0778 *$ & 0.1369 & $0.0218 * *$ \\
\hline CAR $(-10,+10)$ & $-1.98 \%$ & 0.1307 & $-1.87 \%$ & $0.0239 * *$ & $2.37 \%$ & 0.3327 & $-1.38 \%$ & 0.9064 & 0.2868 & 0.2907 \\
\hline
\end{tabular}

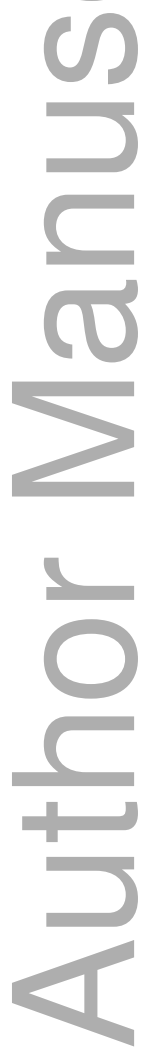

This article is protected by copyright. All rights reserved 
Panel C. Summary statistics for forced turnover announcement date data

The sample period is 1999-2008. The table reports the cumulative abnormal returns (CARs), where the abnormal returns are calculated based on the marketmodel. The market model is estimated using returns from -150 to -31 days from the CEO turnover announced date and uses the CRSP value-weighted index as a proxy for the market portfolio. The CAR is calculated over the $(-t,+t)$ window, where $t=0$ is the day of the CEO turnover announcement. Confounding events such as M\&As, earnings announcements, restatements, and class action lawsuits within $+1 /-1$ day from the CEO turnover announcement day are excluded from the sample.

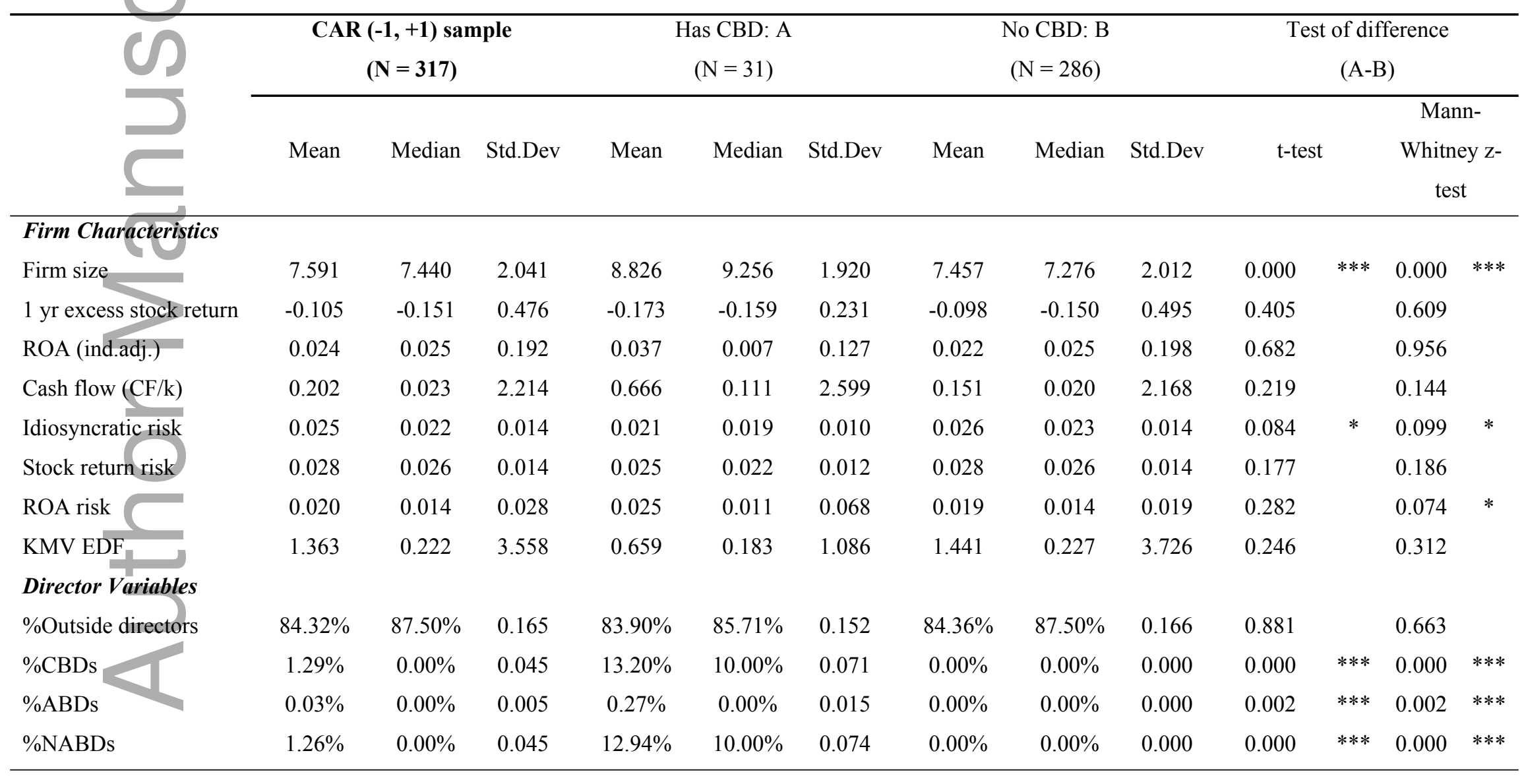

This article is protected by copyright. All rights reserved 


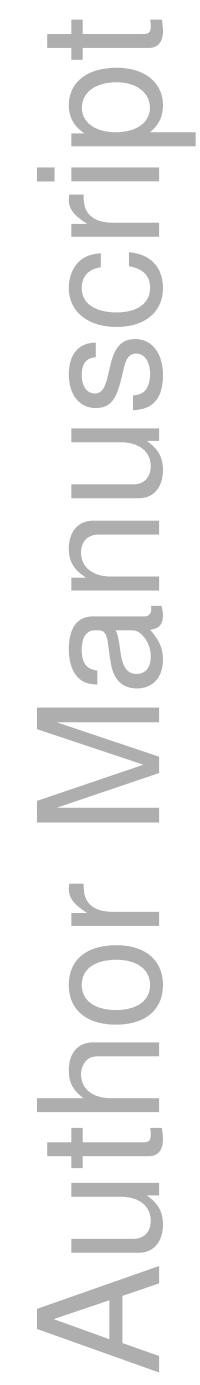

This article is protected by copyright. All rights reserved 


\section{Table 6. CARs around forced CEO turnover - Interaction of CBDs with Performance measures}

The sample period is 1999-2008. The dependent variable is CAR(-1, +1) for firms with forced CEO turnover announcement. In columns (1) - (2), the effect of CBD's existence on CEO turnover announcement is observed and in columns (3) - (8), interaction analysis with performance measure is performed: Performance measure used in (3) - (5) is industry median adjusted ROA and in (6) - (8) is cash flow. Year and industry dummies are included in all specifications. Industry is defined using Fama-French 49 industry classification. *, **, and *** indicate the significance at the $10 \%$, 5\%, and $1 \%$ level, respectively. Standard errors are clustered at the firm level. P-values based on heteroscedasticity robust standard errors are in every second line. Control variables are defined in the Appendix.

\begin{tabular}{|c|c|c|c|c|c|c|c|c|}
\hline \multicolumn{9}{|l|}{ Interaction with Performance measures } \\
\hline \multirow{2}{*}{$\begin{array}{l}\text { Performance measure used: } \\
\text { Dependent variable: CAR }(-1,+1)\end{array}$} & \multicolumn{2}{|c|}{ No Interaction } & \multicolumn{3}{|c|}{ ROA (ind.adj.) } & \multicolumn{3}{|c|}{ Cash flow (ind.adj.) } \\
\hline & (1) & $(2)$ & (3) & (4) & $\overline{(5)}$ & (6) & (7) & $\overline{(8)}$ \\
\hline \multirow[t]{2}{*}{$\%$ Outside Directors } & $0.135 * * *$ & $0.131 * * *$ & $0.15 * * *$ & $0.148 * * *$ & $0.164 * * *$ & $0.139 * * *$ & $0.143 * * *$ & $0.143 * * *$ \\
\hline & $(0.006)$ & $(0.009)$ & $(0.005)$ & $(0.003)$ & $(0.003)$ & $(0.005)$ & $(0.004)$ & $(0.004)$ \\
\hline \multirow{2}{*}{$\% \mathrm{CBD}$} & & $0.276 * *$ & & $0.345 * *$ & $0.361 * * *$ & & $0.354 * *$ & $0.348 * *$ \\
\hline & & $(0.045)$ & & $(0.012)$ & $(0.009)$ & & $(0.014)$ & $(0.016)$ \\
\hline \multirow{2}{*}{ ROA(ind.adj.)*\%Outside Directors } & & & -0.184 & & -0.288 & & & \\
\hline & & & $(0.532)$ & & $(0.315)$ & & & \\
\hline \multirow[t]{2}{*}{$\mathrm{ROA}($ ind.adj.) $* \% \mathrm{CBD}$} & & & & $-1.926 * *$ & $-1.981 * *$ & & & \\
\hline & & & & $(0.028)$ & $(0.027)$ & & & \\
\hline \multirow[t]{2}{*}{ Cash flow(ind.adj.)*\%Outside Directors } & & & & & & 0.008 & & 0.007 \\
\hline & & & & & & $(0.471)$ & & $(0.554)$ \\
\hline \multirow[t]{2}{*}{ Cash flow(ind.adj.)*\%CBD } & & & & & & & $-0.053 *$ & $-0.054 *$ \\
\hline & & & & & & & $(0.092)$ & $(0.082)$ \\
\hline \multirow[t]{2}{*}{ 1yr excess stock return } & -0.014 & -0.013 & & & & & & \\
\hline & $(0.292)$ & $(0.322)$ & & & & & & \\
\hline
\end{tabular}

This article is protected by copyright. All rights reserved 


ROA(ind.adj.)
Rash flow(ind.adj.)

\section{Table 7. CARs around forced CEO turnover - Interaction of CBDs with Risk measures}

The sample period is 1999-2008. The dependent variable is CAR $(-1,+1)$ for firms that announced forced CEO turnover. Risk measure is interacted with director variables: columns (1) - (3) uses winsorized KMV Expected Default Frequency (KMV EDF), and columns (4) - (6) uses change in KMV EDF variable as a risk 
measure. Year and industry dummies are included in all specifications. Industry is defined using Fama-French 49 industry classification. * $* *$, and $* * *$ indicate the significance at the $10 \%, 5 \%$, and $1 \%$ level, respectively. Standard errors are clustered at the firm level. P-values based on heteroscedasticity robust standard errors are in every second line. Control variables are defined in the Appendix.

\begin{tabular}{|c|c|c|c|c|c|c|}
\hline \multicolumn{7}{|l|}{ Interaction with Risk measures } \\
\hline \multirow{2}{*}{$\begin{array}{l}\text { Risk measure used: } \\
\text { Dependent variable: CAR }(-1,+1)\end{array}$} & \multicolumn{3}{|c|}{ KMV Expected Default Risk } & \multicolumn{3}{|c|}{ Chg in KMV Expected Default Risk } \\
\hline & (1) & (2) & $\overline{(3)}$ & (4) & (5) & (6) \\
\hline \multirow{2}{*}{ \%Outside Directors } & $0.094 *$ & $0.153 * * *$ & $0.086 *$ & $0.117 * *$ & $0.123 * *$ & $0.111 * *$ \\
\hline & $(0.065)$ & $(0.006)$ & $(0.098)$ & $(0.013)$ & $(0.015)$ & $(0.021)$ \\
\hline \multirow[t]{2}{*}{$\% \mathrm{CBD}$} & & $0.434 * *$ & $0.437 * *$ & & $0.327 * * *$ & $0.329 * *$ \\
\hline & & $(0.018)$ & $(0.016)$ & & $(0.010)$ & $(0.011)$ \\
\hline \multirow{2}{*}{ KMV EDF*\%Outside Directors } & $0.041 * * *$ & & $0.041 * * *$ & & & \\
\hline & $(0.004)$ & & $(0.003)$ & & & \\
\hline \multirow[t]{2}{*}{$\mathrm{KMV} \mathrm{EDF}^{*} \% \mathrm{CBD}$} & & -0.012 & -0.003 & & & \\
\hline & & $(0.927)$ & $(0.984)$ & & & \\
\hline \multirow[t]{2}{*}{ change in KMV EDF*\%Outside Directors } & & & & $0.032 *$ & & $0.032 *$ \\
\hline & & & & $(0.080)$ & & $(0.077)$ \\
\hline \multirow[t]{2}{*}{ change in $\mathrm{KMV} \mathrm{EDF}^{*} \% \mathrm{CBD}$} & & & & & 0.021 & 0.007 \\
\hline & & & & & $(0.786)$ & $(0.930)$ \\
\hline \multirow{2}{*}{ 1yr excess stock return } & -0.017 & -0.015 & -0.015 & 0.02 & 0.018 & 0.023 \\
\hline & $(0.219)$ & $(0.268)$ & $(0.257)$ & $(0.229)$ & $(0.266)$ & $(0.167)$ \\
\hline \multirow[t]{2}{*}{ ROA (ind.adj.) } & -0.536 & -0.37 & -0.567 & 0.011 & 0.005 & 0.011 \\
\hline & $(0.466)$ & $(0.622)$ & $(0.434)$ & $(0.744)$ & $(0.885)$ & $(0.729)$ \\
\hline \multirow[t]{2}{*}{ Firm size } & -0.003 & -0.003 & -0.003 & -0.004 & -0.004 & -0.004 \\
\hline & $(0.460)$ & $(0.400)$ & $(0.460)$ & $(0.243)$ & $(0.211)$ & $(0.215)$ \\
\hline
\end{tabular}

This article is protected by copyright. All rights reserved 


\begin{tabular}{|c|c|c|c|c|c|c|}
\hline \multirow[t]{2}{*}{$\mathrm{BE} / \mathrm{ME}$} & -0.015 & -0.003 & -0.016 & -0.007 & 0.001 & -0.006 \\
\hline & $(0.390)$ & $(0.839)$ & $(0.365)$ & $(0.708)$ & $(0.938)$ & $(0.756)$ \\
\hline \multirow{2}{*}{$1\{\mathrm{CEO}$ outsider succession $\}$} & 0.002 & 0.003 & 0 & 0.005 & 0.004 & 0.003 \\
\hline & $(0.896)$ & $(0.770)$ & $(0.989)$ & $(0.720)$ & $(0.787)$ & $(0.828)$ \\
\hline \multirow{2}{*}{ KMV EDF } & $-0.028 * * *$ & 0.003 & $-0.028 * * *$ & & & \\
\hline & $(0.006)$ & $(0.318)$ & $(0.004)$ & & & \\
\hline \multirow[t]{2}{*}{ change in KMV EDF } & & & & -0.016 & $0.009 * * *$ & -0.016 \\
\hline & & & & $(0.284)$ & $(0.006)$ & $(0.291)$ \\
\hline \multirow[t]{2}{*}{ constant } & 0.101 & 0.035 & 0.083 & $-0.305 *$ & $-0.347 * *$ & $-0.317 *$ \\
\hline & $(0.380)$ & $(0.764)$ & $(0.485)$ & $(0.060)$ & $(0.034)$ & $(0.052)$ \\
\hline \multirow{2}{*}{$\begin{array}{l}\text { Industry FE } \\
\text { Year FE }\end{array}$} & Yes & Yes & Yes & Yes & Yes & Yes \\
\hline & Yes & Yes & Yes & Yes & Yes & Yes \\
\hline \multirow{2}{*}{$\begin{array}{l}\mathrm{N} \\
\text { Adj.R2 }\end{array}$} & 310 & 310 & 310 & 308 & 308 & 308 \\
\hline & 0.087 & 0.078 & 0.114 & 0.096 & 0.092 & 0.11 \\
\hline
\end{tabular}

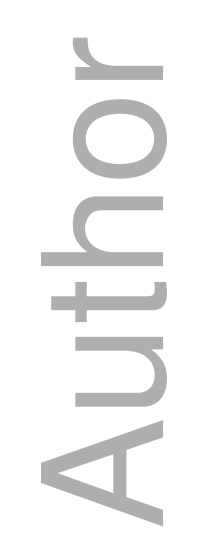

This article is protected by copyright. All rights reserved 


\section{Table 8. Changes in ROA and CBDs}

The sample period is 1999-2008. OLS regression is performed where the dependent variable is industry median adjusted change in ROA from year 0 to +1 , which $\mathrm{t}=0$ is the year when CEO turnover was announced. Year and industry dummies are included in all specifications. *, ${ }^{* *}$, and $* * *$ indicate the significance at the $10 \%, 5 \%$, and $1 \%$ level, respectively. Standard errors are clustered at the firm level. P-values based on heteroscedasticity robust standard errors are in every second line. Control variables are defined in the Appendix.

Dependent variable: Chg in $\operatorname{ROA}(0,+1)$

(1)

(2)

(3)

\begin{tabular}{|c|c|c|c|}
\hline \%Outside Directors & $\begin{array}{l}-0.121 * * \\
(0.016)\end{array}$ & $\begin{array}{l}-0.057 \\
(0.132)\end{array}$ & $\begin{array}{l}-0.091 * \\
(0.062)\end{array}$ \\
\hline$\% \mathrm{CBD}$ & & $\begin{array}{l}0.707 * * \\
(0.018)\end{array}$ & $\begin{array}{l}0.685 * * \\
(0.022)\end{array}$ \\
\hline ROA*\%Outside Directors & $\begin{array}{r}0.416 \\
(0.155)\end{array}$ & & $\begin{array}{r}0.29 \\
(0.281)\end{array}$ \\
\hline $\mathrm{ROA} * \% \mathrm{CBD}$ & & $\begin{array}{l}-5.36 * \\
(0.083)\end{array}$ & $\begin{array}{l}-5.206 * \\
(0.092)\end{array}$ \\
\hline ROA & $\begin{array}{r}-0.44 \\
(0.139)\end{array}$ & $\begin{array}{l}-0.026 \\
(0.488)\end{array}$ & $\begin{array}{l}-0.303 \\
(0.262)\end{array}$ \\
\hline idiosyncrat & $\begin{array}{l}1.342^{* * *} \\
(0.006)\end{array}$ & $\begin{array}{l}1.32 * * * \\
(0.001)\end{array}$ & $\begin{array}{l}1.212^{* * * *} \\
(0.007)\end{array}$ \\
\hline Firm size & $\begin{array}{r}0.002 \\
(0.577)\end{array}$ & $\begin{array}{r}0.002 \\
(0.627)\end{array}$ & $\begin{array}{r}0.001 \\
(0.799)\end{array}$ \\
\hline $\mathrm{BE} / \mathrm{ME}$ & $\begin{array}{l}0.01 * * * \\
(0.006)\end{array}$ & $\begin{array}{l}0.009 * * * \\
(0.003)\end{array}$ & $\begin{array}{l}0.009 * * \\
(0.010)\end{array}$ \\
\hline $1\{$ CEO outsider succession $\}$ & $\begin{array}{r}0 \\
(0.978)\end{array}$ & $\begin{array}{l}-0.004 \\
(0.729)\end{array}$ & $\begin{array}{l}-0.004 \\
(0.725)\end{array}$ \\
\hline constant & $\begin{array}{l}-0.104 \\
(0.143)\end{array}$ & $\begin{array}{l}-0.172 * * * \\
(0.000)\end{array}$ & $\begin{array}{l}-0.119 * \\
(0.091)\end{array}$ \\
\hline $\begin{array}{l}\text { Industry FE } \\
\text { Year FE }\end{array}$ & $\begin{array}{l}\text { Yes } \\
\text { Yes }\end{array}$ & $\begin{array}{l}\text { Yes } \\
\text { Yes }\end{array}$ & $\begin{array}{l}\text { Yes } \\
\text { Yes }\end{array}$ \\
\hline$\overline{\mathrm{N}}$ & 336 & 336 & 336 \\
\hline Adj.R2 & 0.054 & 0.112 & 0.114 \\
\hline
\end{tabular}




\section{Table 9. Changes in Risk measure and CBDs}

The sample period is 1999-2008. In Panel A, OLS regression is performed where the dependent variable is change in Idiosyncratic risk from year 0 to +1 , which $\mathrm{t}=0$ is the year when CEO turnover was announced. In Panel A, columns (1) - (3) include interaction with $1\{$ High change of Idio.risk (-2, -1$)\}$, which represents a dummy variable where the variable equals one if the change of Idiosyncratic risk $(-2,-1)$ is in the $4^{\text {th }}$ quartile and zero otherwise, and columns $(4)-$ (6) use interaction with the level variable of idiosyncratic risk measured at 1 year prior to the CEO turnover. In Panel B, the dependent variable is change in ROA risk from year 0 to +1 from columns (1) - (3) and change in ROA risk from year 0 to +2 from columns (4) - (6). Year and industry dummies are included in all specifications. * $* *$, and $* * *$ indicate the significance at the $10 \%, 5 \%$, and $1 \%$ level, respectively. Standard errors are clustered at the firm level. P-values based on heteroscedasticity robust standard errors are in every second line. Control variables are defined in the Appendix.

Panel A. Idiosyncratic risk

\begin{tabular}{|c|c|c|c|c|c|c|}
\hline Dependent variable: change in Idio.risk $(0,+1)$ & $(1)$ & (2) & (3) & (4) & $(5)$ & (6) \\
\hline \multirow[t]{2}{*}{$\%$ Outside Directors } & -0.003 & -0.005 & -0.004 & 0.019 & -0.002 & 0.019 \\
\hline & $(0.709)$ & $(0.596)$ & $(0.678)$ & $(0.257)$ & $(0.819)$ & $(0.257)$ \\
\hline \multirow[t]{2}{*}{$\% \mathrm{CBD}$} & & 0.002 & 0.003 & & 0.072 & 0.072 \\
\hline & & $(0.922)$ & $(0.902)$ & & $(0.109)$ & $(0.113)$ \\
\hline \multirow{2}{*}{ High change of Idio.risk $(-2,-1)$}$* \%$ Outside Directors & -0.011 & & -0.015 & & & \\
\hline & $(0.560)$ & & $(0.451)$ & & & \\
\hline \multirow[t]{2}{*}{ High change of Idio.risk $(-2,-1)$}$* \% \mathrm{CBD}$ & & $-0.095 *$ & $-0.100 *$ & & & \\
\hline & & $(0.091)$ & $(0.061)$ & & & \\
\hline \multirow{2}{*}{ Idiosyncratic risk $\mathrm{t}_{\mathrm{t}-1} * \%$ Outside Directors } & & & & -0.843 & & -0.818 \\
\hline & & & & $(0.168)$ & & $(0.195)$ \\
\hline \multirow{2}{*}{ Idiosyncratic risk $\mathrm{t}_{\mathrm{t}-1} * 0 \mathrm{CBD}$} & & & & & $-2.958 * *$ & $-2.904 * *$ \\
\hline & & & & & $(0.039)$ & $(0.048)$ \\
\hline \multirow[t]{2}{*}{ High change of Idio.risk $(-2,-1)$} & 0.007 & 0.000 & 0.011 & & & \\
\hline & $(0.635)$ & $(0.933)$ & $(0.456)$ & & & \\
\hline
\end{tabular}

This article is protected by copyright. All rights reserved 


\begin{tabular}{|c|c|c|c|c|c|c|}
\hline \multirow[t]{2}{*}{ idiosyncratic risk $_{\mathrm{t}-1}$} & & & & 0.477 & -0.172 & 0.468 \\
\hline & & & & $(0.326)$ & $(0.181)$ & $(0.344)$ \\
\hline \multirow{2}{*}{ 1yr excess stock return } & -0.001 & -0.001 & -0.001 & -0.002 & -0.002 & -0.002 \\
\hline & $(0.300)$ & $(0.382)$ & $(0.353)$ & $(0.186)$ & $(0.180)$ & $(0.146)$ \\
\hline \multirow{2}{*}{ ROA (ind.adj.) } & -0.02 & $-0.023 *$ & $-0.024 *$ & $-0.027 * *$ & $-0.024 *$ & $-0.027 * *$ \\
\hline & $(0.129)$ & $(0.092)$ & $(0.093)$ & $(0.042)$ & $(0.071)$ & $(0.037)$ \\
\hline \multirow{2}{*}{ Firm size } & 0.000 & 0.000 & 0.000 & 0.000 & 0.000 & 0.000 \\
\hline & $(0.826)$ & $(0.697)$ & $(0.799)$ & $(0.655)$ & $(0.728)$ & $(0.593)$ \\
\hline \multirow[t]{2}{*}{$\mathrm{BE} / \mathrm{ME}$} & 0.000 & -0.001 & -0.001 & 0.000 & 0.000 & -0.001 \\
\hline & $(0.890)$ & $(0.807)$ & $(0.748)$ & $(0.857)$ & $(0.906)$ & $(0.775)$ \\
\hline \multirow{2}{*}{$1\{$ CEO outsider succession $\}$} & 0.001 & 0.002 & 0.002 & 0.002 & 0.002 & 0.002 \\
\hline & $(0.550)$ & $(0.470)$ & $(0.463)$ & $(0.484)$ & $(0.429)$ & $(0.446)$ \\
\hline \multirow{2}{*}{ constant } & 0.006 & 0.006 & 0.006 & 0.001 & 0.012 & 0.000 \\
\hline & $(0.501)$ & $(0.515)$ & $(0.487)$ & $(0.912)$ & $(0.281)$ & $(0.974)$ \\
\hline Industry FE & Yes & Yes & Yes & Yes & Yes & Yes \\
\hline Year FE & Yes & Yes & Yes & Yes & Yes & Yes \\
\hline$\overline{\mathrm{N}}$ & 205 & 205 & 205 & 205 & 205 & 205 \\
\hline Adj.R2 & 0.073 & 0.077 & 0.074 & 0.099 & 0.094 & 0.101 \\
\hline
\end{tabular}

Panel B. ROA risk

\begin{tabular}{|c|c|c|c|c|c|c|}
\hline \multirow{2}{*}{ Dependent variable: } & \multicolumn{3}{|c|}{ change in ROA risk $(0,+1)$} & \multicolumn{3}{|c|}{ change in ROA risk $(0,+2)$} \\
\hline & (1) & $(2)$ & (3) & (4) & $(5)$ & (6) \\
\hline \multirow[t]{2}{*}{ \%Outside Directors } & $0.007^{*}$ & 00.000 & 0.001 & $0.014 * *$ & 0.003 & 0.001 \\
\hline & $(0.095)$ & $(0.955)$ & $(0.808)$ & $(0.026)$ & $(0.469)$ & $(0.821)$ \\
\hline
\end{tabular}

This article is protected by copyright. All rights reserved 




This article is protected by copyright. All rights reserved 


\section{Footnotes}

${ }_{1}$ Boardex is a database that contains information of more than 300,000 unique board members of publicly-listed companies in the United States and around the world.

${ }^{2}$ BoardEx database provides limited one-to-one link information for 8,622 unique firms in Compustat via CIK and we find that BoardEx ID is unique depending on the spelling of a company's name that each director claims. With this respect, multiple company ID's in BoardEx are not matched with the same company in Compustat, leading us to run extensive text matching algorithms.

${ }^{3}$ If an observation is missing, we manually fill it by reading news articles obtained from Factiva.

${ }^{4}$ It is the same data that was used in Jenter and Kanaan (2015)

${ }^{5}$ Specifically, when searching newspaper articles in Factiva, we classify a succession as a forced turnover if the news articles report that the CEO is fired, forced, ousted, or departed due to unspecified policy differences. For the remainder of the transitions, if the incumbent CEO is under the age of 60 and the news articles do not report the reason for the departure such as involving death, poor health or accepting other positions elsewhere or within the firm, we classify such cases as forced turnovers. In addition, if the departing CEO's accepted new position is with a private consulting business, such case is considered to be a forced turnover because the move is from a big public corporation (typically top 1500 largest public firms in the US) to a smaller private company. However, moves to the federal or local government are not classified as forced. Besides, a "retirement" announcement of a CEO younger than 60 years old is considered to be a forced turnover if the succession plan was not announced at least six months prior to the actual transition.

${ }^{6}$ In our untabulated analyses, we also use the annual excess stock return, which is calculated by annualizing 12 months of monthly stock returns and subtracting the CRSP value-weighted index, and find qualitatively similar results.

${ }^{7}$ For all missing SIC codes, the industry is defined as industry 49.

${ }^{8}$ In an untabulated analysis, we tried a negative net income dummy and a 1-year excess stock return as our performance measure in lieu of industry median adjusted ROA and found qualitatively consistent results.

${ }^{9}$ With respect to the concerns related to the interaction terms of logit models (see Ai and Norton, 2003), we have performed the INTEFF analyses following Norton, Wang and Ai (2004). Since we cannot run the INTEFF function when there are more than two interaction terms in one regression - i.e. $\mathrm{A} * \mathrm{~B}$ and $\mathrm{A} * \mathrm{C}-$ we reran the logit models of Tables 3 and 4 by including only one interaction term for each regression. That is, we ran $\mathrm{A}, \mathrm{B}$, and $\mathrm{A} * \mathrm{~B}$ for one regression and $\mathrm{A}, \mathrm{C}$ and $\mathrm{A} * \mathrm{C}$ for another regression and so on. Generally, after running the INTEFF function for our logit models, the coefficient sign and statistical significance holds similar as our Tables 3 and 4.

${ }^{10}$ Confounding events include M\&As, earnings announcements, restatements, interim-CEO or new CEO appointments, and class action lawsuits. We remove the observations if the aforementioned confounding events took place 15 calendar days before or after the CEO turnover announcement date.

${ }^{11}$ Other models, such as the equally weighted market index model, Fama French 3 factor model, or Fama French 4 factor model, show similar inferences on CARs for forced turnover announcements.

${ }^{12}$ Using natural $\log$ of sales to proxy for firm size yields qualitatively similar results.

13 Although not reported in this paper, Industry clustering or two-dimensional clustering, where it is clustered at firm- and year-level, show qualitatively similar inferences.

${ }^{14}$ In the subset of data, we only have 1 firm-year that has affiliated bankers on the board.

${ }^{15}$ In unreported regressions, when fractions of outside directors are split into banker directors and nonbanker directors, we find that both types of directors have positive association with the forced CEO turnover announcement returns. What is interesting is that when there are more banker directors on the board, the forced turnover announcement is more positive compared to when there are more non-banker 
directors on the board and the difference between these two coefficients is statistically different at 5\% significance level. This finding implies that banker's existence on the board has more positive association than that of non-banker directors on CEO turnover announcement effect, supporting our H3.

${ }^{16}$ However, these ROA changes are not statistically different from firms with banker directors compared to firms without banker directors for all periods.

${ }^{17}$ Change of idiosyncratic risk is considered high when the change from $t=-2$ to $t=-1$ is in the upper $25 \%$ among the data sample.

18 They may self-select to sit on certain boards of firms with less risk, larger size, lower information asymmetry, and lower short-term to long-term debt ratio to avoid bankruptcy (see Kroszner and Strahan, 2001)

${ }^{19}$ Please contact the author for details of the untabulated analyses.

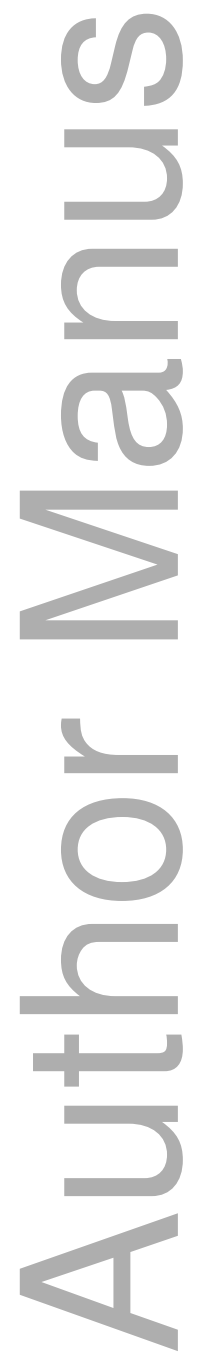

